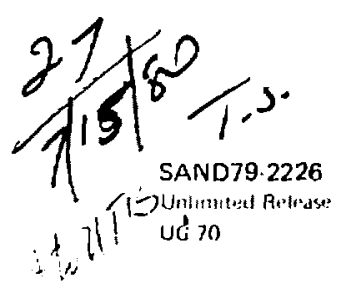

\title{
Salt Block II: Description and Results
}

Jacque J. Hohlfelder

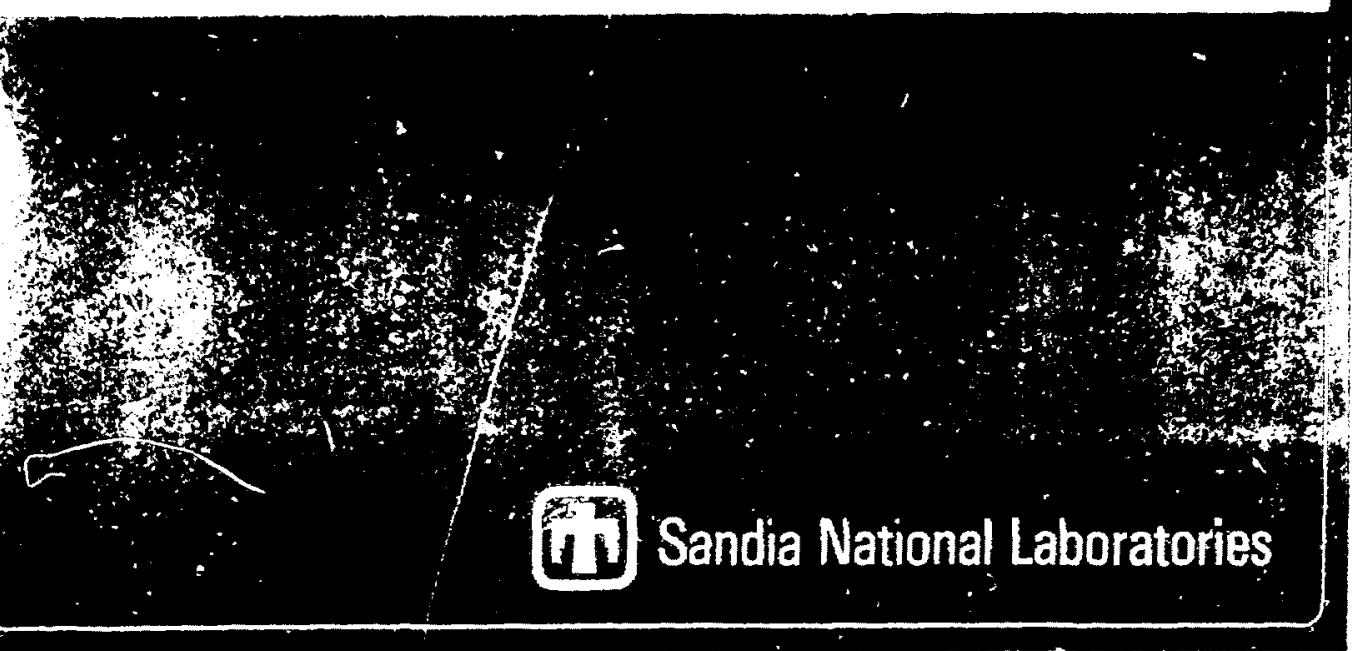


UC-70

\author{
SNDD79-2226 \\ Uniditited Relense
}

GALT BLOCK II: DFSCRIPTION NDD RESULTS

J. J. Hohlfelder

Division 1112

Sandia National Laboratories

Albuquerque, New Mexico 87185

\begin{abstract}
ABSTRNCT
A description of and results from the salt Block II experiment, which involved the heating of and measurement of water transport within a large sample of rock salt, are presented. These resul to include the measurement of water released into a heated borehole in the somple as well as weasured tenperatures within the salt. Measured temperatures are compared with the results of a nathematical model of the experinent.
\end{abstract}

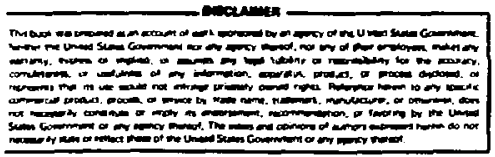




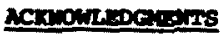

The persistent hard work of many individula contributed to the auccessful performance of this exper Lent. The araistance of the following persons is gretetully coknowledged: Jay Benson (decesed), Richard Bafe (1124), Austin Arthur (1125), Janes Johneon (1125), John Loukota (1125), Jenes HeIlnoyle (1125), Frank Dean (1761), Btephen bresze (2452), John stott (retired), Henry Bhegelbine (4541), Alian Battler (4732), Inon Villager (4733), and oucer Ceorge (5511).

\section{Presce}

This document is deseription of the salt block II experiment and a sumery of the oxperient's mujor events. It presents a caplete, though tentative, aumary of the experinont"s wete tranport dota a well as afficient thernal date to enable detalied, quntitetive weter transport nodeling. 


\section{Inmooverrou}

The salt Block II experiment was a laboratocy experiment involving the heating of and mesurement of mter transport within a large epecisen of bedded geologic salt. The two principel technical obfectives of the test were:

1. The quantitative, time-dependent, redundant masurement of the water released Into a heated borehole in a large $(2$ ton) sample of rocksalt.

2. The measurement of temperature: and of heat flux at selected locations within the salt sample, its heater, and its enclosure. The purpose of these weasurements is to provide for a comparison with the predictions of a mathmatical wodel of this experinent.

The release of water into a houted borehols is of interent because arguments have been advanced, which atate that this phenomenon could degrads the ability of a nuclear wate repository in bedded calt to leolate radionuclides from the biosphere. sines this traneport of wher (including the phencmenon, "brine-migration") may be governed by both temperature and temperature gradient, accurate knowledge of thase parameters withln the salt block are essential.

\section{EXPERIYEGT DESCRIPRTOU}

The experiment consisted of a 1-meter-dieneter by 1-meter-high cylindr1cal block of rockealt with a bochole 0.13-meters dianeter by 0.8-meters deep on its axis for an electrical heter. The block ins placed inside a gas-tight stainleas steel container whe outside circueference wa cooled with a water jecket. The thermal field within the block we seasured with thermocouples and heat flux gages that wre installed on the electrical heater, within the salt block, and on its outside surface. Water release from the heated bocehole we neusured by contl nuously purging the senled borehole with very dy nitrogen gas and measuring the water content in the 
exhaust gas with two independent technigues. Data were automatically recorded by a computer-baned data scquisition syates.

A simplified schematic and a photograph of the assembled experiment are whow in Figures 1 and 2 . The mafor componente of the experient were the calt block, the heater and weter jecket watems, the temperature censors, the moleture measurement system and the date scquisition rysten, all of which are deser lbed below.

\section{Salt Block}

The salt block (Figure 3) was axchined from a large block of bedded salt obtalned from the Miseiseippl Chenical Company's potash mine in woutheastern New Nexico. The total volati?e content, wost of wich is water, of this salt ranges between 0.1 and 0.5 percent by wight. Both the mineralogy of the salt block ard its strese state may be different from the in situ conditions at the proposed MIPP horizons, therefore, the witer releace rates beasured in this exporiment any be different from those in the mpp facility.

\section{Beater and water Jesket syate.}

The thermal environient in the block wes deternined by the electrical heater along its sxis and by the controlled thermal boundary conditions of the walt block's enclosure. The boundery conditions were defined by a water cooling jacket around the drcuference and by thermal Insulation on the top and bottom of the block. At the maximin hater power of 1.5 kllowatts, the maximu temperature and telperature gradient at the surface of the heater hole were about $200{ }^{\circ} \mathrm{C}$ and $12^{\circ} \mathrm{C} / \mathrm{cm}$, reepectively.

\section{Temperature Marurcant}

The thermal field in the ealt block wa wasured and predicted theoreticaly as a function of tise and postion (both axially and radially). The experinent we instrunented with approximately 40 thersocouples and 10 heat flux gages. A two-dinensional, finite-difference model was used to predict the time-dependent terperatures within the block. For the mont part the parameters used in the wodel wre either known aterials properties or measured boundary condition values. Bowever, the telperature-dependent theranal conductivity of the salt we adjusted so that measured temperatures watched the calculated ones. 


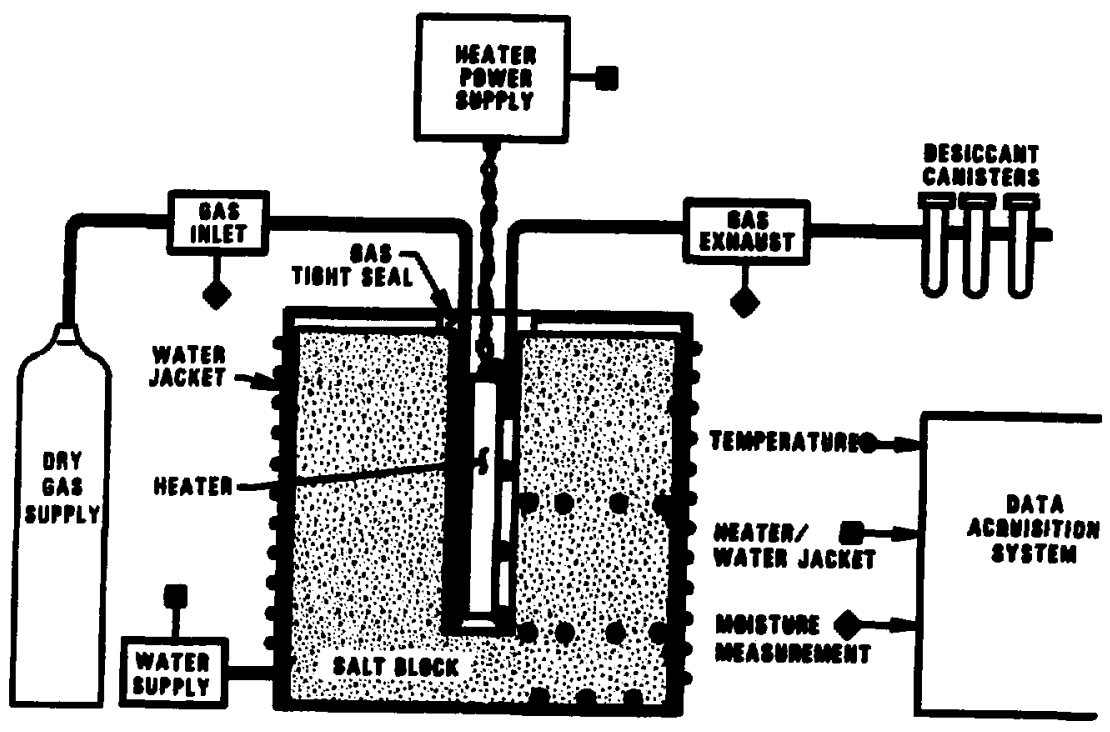

Figure 1. SCHEMATIC OF THE SALT BLOCK II EXPERIMENT 


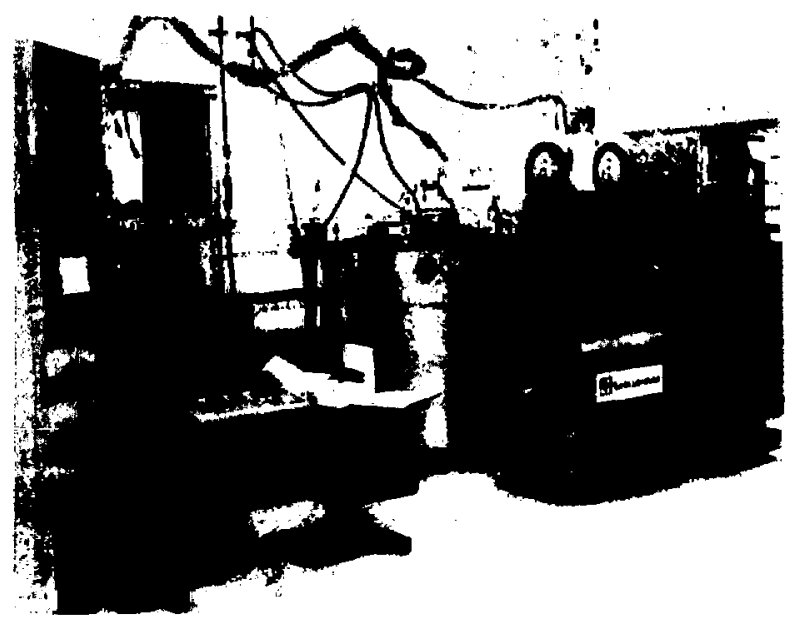

Figure 2. ASSEMBLED SALT BLOCK II EXPERIMENT

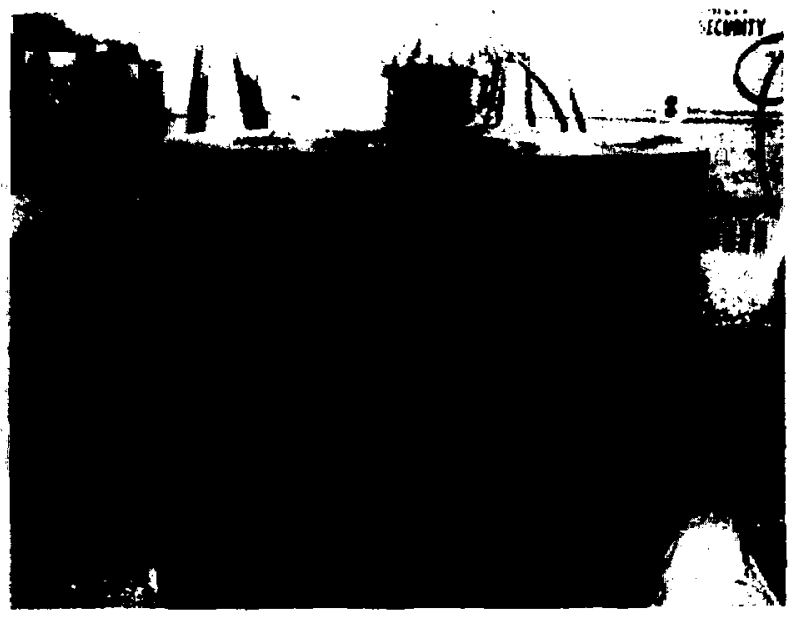

Figure 3. SALT BLOCK II PRIOR TO PLACEMENT IN ENCLOSURE

$-4-$ 


\section{Mofsture collection syate.}

As shown in Figure 1, any soloture released in the heater hole was removed by purging the annular volune between the heater can and the heater hole with very dry nitrogen gac. The enount of meter in the purge gate wat determined by two techniques,

1) The temperature, pressure, dew point and flow rate of the purge gas (both inlet and exhaust) were measured and used to calculate the rate ot hilich water we being extracted from the wit. The rate was Integrated to yield the cunulative water releace.

2) The purge gas exhaust was passed through mater-specific, desiccant canisters. These caniaters were changed periodically and accurately weighed before and after use. The wight gain of the canisters was taken to be the anount of water in the purge gas.

These two technlques for masuring water lose were evoluated, and they proved to be consistent within about 10 parcent in a series of experinente on small rocksalt anplen. 1

\section{Data Requisition syete.}

Data from the 120 channele of diegnostic inatruantation generated during the course of the experinent were sutanatically recorded by a computer-based data-acquisition system. This syaten sapled the sensors at specified intervals, digitized the outputs, converted them to engineering units, and then calculated the rate of moleture relense from the mensured preseure, temperature, dew point and flow-rate data.

\section{Evar sueapY}

A discusaion of the experinent's major events is presented here. some of these were unexpected, but in genaral, water transport measurements and thermai field measurements continued uninterrupted until the experifent's conclusion.

The experinent began november 28, 2978. After six days, heater power was applied and increased in discrete steps through January 3, 1979, at wich time the prower was increased from $0.6 \mathrm{kH}$ to $1.0 \mathrm{kH}$. 
On January 9, an unexpected power outage resulted in the lost of electrlcal power to the experiment's henter. The outage lasted about 30 minutes. Water cooling of the salt block's enclosure continued, and temperatures of the salt block and heater declined.

The $1.5 \mathrm{kH}$ heating phase began on Janaury 16 . On January 24, a broken water main caused a lose of the experiment's cooling water for abost 16 houra. The maximu temperature increace in the enlt block, which occurred near ite top surface, was about $20^{\circ} \mathrm{C}$.

During the remainder of the $1.5 \mathrm{kH}$ heating phase, several gages becane inoperative or unreliable, although no elgniflcant data were lost due to these gage failures. The water flow rate gages and several heat flux gages failed. The dew polnt gages becues lese reliable because of frequent fouling. After February 19 , only the desiccant canister wethod was used to measure water evolved into the borehole region. Both the heater current and voltage were monsured, and the heater power wa calculated from these quantities. A low increace in the temperatures within the selt was observed; this was caused in pact by the rive in the temperature of the cooling water from 1to wintar minimen.

The shutdown phace bagan on March 26, 1979, and consiated of three, enquential heater power reductions. Beater power wae reduced from $1.5 \mathrm{kH}$ to $1.0 \mathrm{~kW}$, from $1.0 \mathrm{kH}$ to $0.6 \mathrm{kH}$, and from $0.6 \mathrm{~kW}$ to $0 \mathrm{kH}$. Following ench heater power reduction, the experinent continued at constant heater power for approxinately on week.

Following each of the heater power reductions occurring during the shutdown phase, transient and relatively large wher inflow rates were measured. This plienomenon ws expected, baeed upon earlier measurements of water lost frow heated $1 \mathrm{~kg}$ ult samples. Whter lost during the shutdow phace accounted for a large fraction ( 43 percent) of the water madured during the courne of the exper inent.

At the end of the shutdown phase, the masurements of water evolved into the heater region were terminuted, and the experiment's disansembly was started April 16, 1979. The discansembly phase (including the end of all ective seneor recording, removal of the experiment's cover and shell, and evaluation of the effect: of the experiment on the salt block, the heater, and the seals) lasted two days. 
Following removal of meter-cooling 11 nes, electrical leads, and gas-fl.iow plumbing, the experiment dienenembly continued with the removal of the lesk seal material from the top of the hater, and the removal of the gas aeal bellowe, the experibent cover, and the cylindrical shell. Little evidence of water or water tranport in the region between the cylindrical shell and the ualt block we present. Approximately 1 g of mter resained as condensete-prinarily on the periphery of the botton plate. Traces of corrosion were present on the stainless ateel expertental aterials. Visible evidence of fluid traneport occurred only as thin ealt cruste in isolated regions around the outer surface of the wlt block, but occurred wore generally on the inner surface of the salt block in the region surrounding the heater. Renoval of the cruched alt backfill from around the hater and the.t removal of the heater wa simple. Encentially all of the backflil material was recovered. The heater wa lifted from the borchole and showed very little corrosioni no borehole deforation or canenting of the hater with beine encrustation was evident. Some cracking and sparation of the ealt block along its horizontal bedding planes occurred, but these crecke were limited to approxinately the middle one-third of the block $11.4 .$, the 0.3 a thick, cylladrical eaction located oymatel illy about the block's horitontal aldplane) and did not oxtend into the region currounding the heater. Deplte the cocurrence of thit eracking within the salt, the salt we sufficiently intact so that the salt block could be lifted by the call at ito top eurface. Wo cracking between thernocouple bortholes cocurred, and the seale in these holes appeared unaltered. The electomeric gas ceal betwen the heater collar and the salt block we not only intact, but lte cumaive bond we sufficient to support the ane of the salt block. In genaral, the hat flux gage achesive bonds renalned intact, including thoee bonded to the surfece of the heater.

rollowing experinent diesenebly, post-test wepling of the salt block continued intermittently unt1l about July 1. meoval of material janples from the enlt block we a protracted operation lasting two months. In order to renove auples from a region within the block that had experienced large temperature changes, a one-foot-thlck cylindrical slab wae hand am from the top of the salt block. galt anples wre removed fron the anterial exposed on this "freshly" cut arface. Additionelly, around Jure 25, four 
1-Inch-dianeter vertically oriented cores wre removed from the material below the freahly cut surface. The core centers were at varying radial distances from tice axis of the ealt block. Specinene trom both wets of salt saples wre exanined for mear content.

The experimental ovente are listed here in chronological order:

Date

Novewber 28, 1978 :

Decent I 4, 1978:

December 11, 1978:

Decenber 18, 1978:

January 2, 1979 :

January 8, 1979 ,

January 16, 1979:

January 24, 1979 !

March 26, 1979:

Apr11 2, 1979:

Apr 12 9, 1979,

Apri1 16, 1979:

Apr 11 16-30, 1979,

May-June, 1979:
Event Description

The experient we started (water tranepert masurementel, but with no hater power.

Heater porer we turned on at level of $0.2 \mathrm{~kW}$.

Heater power we raised fron $0.2 \mathrm{kil}$ to $0.4 \mathrm{~kW}$.

Heater power we raised from $0.4 \mathrm{kH}$ to $0.6 \mathrm{kH}$.

Heater poiver we raleed from $0.6 \mathrm{kH}$ to $1.0 \mathrm{~kW}$.

Power outige (approxinately 0.5 hour).

Hoater power was raised erom $1.0 \mathrm{kH}$ to $1.5 \mathrm{~kW}$.

inter jecket cooling interruption.

Shutdown phaes started, heater power reduced from $1.5 \mathrm{kH}$ to $1.0 \mathrm{kH}$.

Heater power reduced Erom $1.0 \mathrm{kH}$ to $0.6 \mathrm{kH}$.

Beater power turnad off.

Ine experifent we turned ofe (water transport measurcments terninated).

The experiment wa disasmebled and Inepected. Post-test saples from the ealt block were obtained. 


\section{Rovorex:}

Both of the experimentel objectives ou'ilined in the introduction have been met, and water tranmport meavurement and thereal behavior results ere presented below.

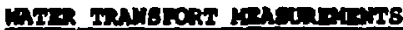

A sunary of the mejor result for each hating phase of the salt Ble :II experient, including thernel and water loss data, is show in rat. I. Only 111.4 ge of water wes released during the approxinately 140-day-long experiment. A mator fraction of the water erolved (45 percent) was released during the 10-week 10ng, $1.5 \mathrm{kH}$ helter power phase; hovever, 43 percent of the water wa released during the three-wesk-long shutdown phase. The greatest wher release rates were oberved following heater power decreases. Altho'zh the axinum thermal gradient at the hater borehole surface is tabulated, nothing in the resulte indicate that this is a ignificant paraneter in underetanding water truneport in salt on this physical scale. The absolute value of the radiel component of calculated values of the equilibrium thermal gradient within the salt block are presented in the section, "rabusk BaHAviOR." As indleated in the lant colum of Table $I$, a relatively high average rate of weter releace occure in the first two day following any change in the heater pover, this is wost pronounced in two Instances in which the heater power wa reduced,

A more detailed sumary of the water mass loss measurements is presented in Table II. The table lists wher ans loss results determined by each of two Independent wethods. Timo-dependent nase lnse rates were celculated from the measurement of the dow point and gas flow pareneters (volune flow rate, absolute pressure, and temperature) of the nitrogen gas atrean which scavenged water from the region between the borebole and the heater. The integral of the mter ans lose rate yielded the total sacs of water lost over the integral's tine interval. Shom in rable II are vaiues of this integral evaluated from times identical to those at wich desiccant canister neasurements of water anse were made. The errors reported for the mass rate 
ters 1

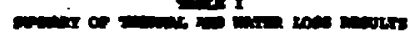

\begin{tabular}{|c|c|c|c|c|c|c|c|}
\hline $\mathbf{m}$ & & & b. & e & 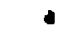 & - & $\varepsilon$ \\
\hline 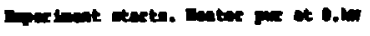 & 301.95 & $\bullet . \bullet$ & $\mathbf{0 . 0}$ & $\mathbf{2 0 . 3}$ & $\mathbf{2 s , 4}$ & -- & - \\
\hline 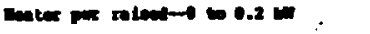 & 397.40 & $\bullet . \bullet$ & 0.297 & 35.5 & s2.3 & 3 & -1.2 \\
\hline 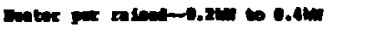 & 244.452 & 0.185 & 6.33 & 3.3 & $\mathbf{M . 0}$ & $\mathbf{5}$ & -2.3 \\
\hline 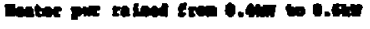 & 351.43 & 0.35 & e.ses & 72.3 & 115.6 & $\mathbf{a}$ & -4.1 \\
\hline 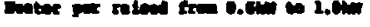 & 1.07 & C.51 & 1.60 & 113.5 & $\mathbf{3 0 3 . 0}$ & $\mathbf{w}$ & -7.6 \\
\hline 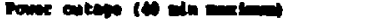 & 0.62 & 2.60 & - & 100.4 & $\mathbf{2 3 . 2}$ & - & - \\
\hline 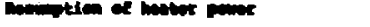 & 0.300 & - & 1.6en & - & - & - & - \\
\hline 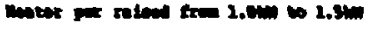 & 25.sen & i.w & 1.) & $\begin{array}{l}271.15 \\
27.1\end{array}$ & 2ms.es & 20,2001 & $\begin{array}{l}-22.75 \\
-12.0\end{array}$ \\
\hline 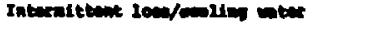 & 23.cea & 2.53 & 2.54 & 101.3 & $\mathbf{3 2 . 3}$ & - & - \\
\hline 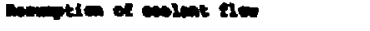 & 24.371 & 2.55 & 1.543 & 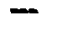 & & - & - \\
\hline 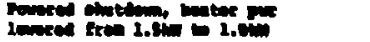 & C4.414 & 1.525 & 1.6. & 121.1 & 293.2 & $\mathbf{w}$ & $\rightarrow .1$ \\
\hline 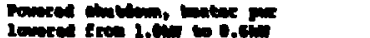 & 22.34 & 1.en & c.me & 0.3 & 28.2 & $m$ & -4.5 \\
\hline 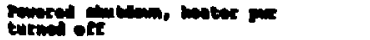 & 9,401 & c.ent & - & 20.4 & 10.4 & 15.4 & - \\
\hline 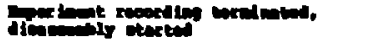 & 183.342 & - & - & - & - & - & 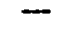 \\
\hline
\end{tabular}




\begin{tabular}{|c|c|c|c|c|c|c|c|}
\hline 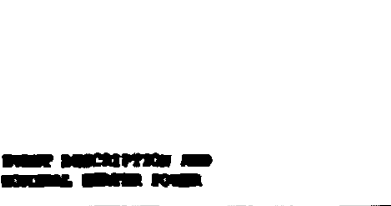 & $\sum_{n=0}^{n-1}$ & 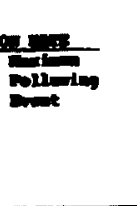 & 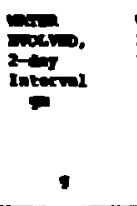 & $\frac{1}{n}$ & 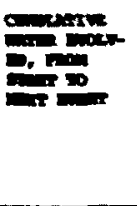 & - & 201 \\
\hline 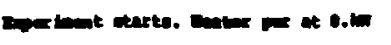 & 一 & $0.21=10-5$ & $.214 \pm .023$ & $.273 \pm .019$ & $.273 \pm .06$ & 3.90 & 1.4 \\
\hline 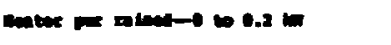 & $2 .=20-5$ & $9.95=10^{-3}$ & $.2 n \pm \cdot \omega 1$ & .406 & $m$ & 6.9 & 2.3 \\
\hline 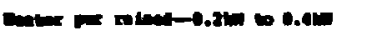 & $2.21=20-5$ & $9.63=100-5$ & $.203 \pm .042$ & .537 & .232 & 7.03 & 2.2 \\
\hline 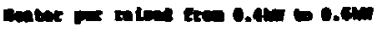 & $2.50=20-5$ & $1.53=10-4$ & $. m \pm .29 s$ & 1.21 & 2.32 & 16.90 & 1.7 \\
\hline 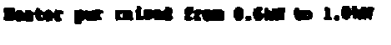 & $2.11=20-5$ & $1.36=10^{-3}$ & $2.60 \pm .73$ & 10.69 & 13.21 & 10.67 & 1.3 \\
\hline 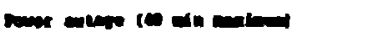 & $2.14=100$ & $1.20=20^{-2}$ & $0.7 \pm 1.57$ & 11.69 & 23.21 & 16.07 & 3.2 \\
\hline 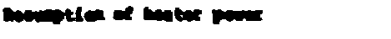 & - & - & - & - & - & - & - \\
\hline 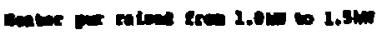 & $1.60=100$ & $4.73=20^{-3}$ & $3.32 \pm 2.12$ & 4.97 & 63.18 & $\omega .67$ & 2.3 \\
\hline 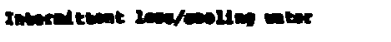 & $6.16 \times 10-1$ & $1.02=10^{-3}$ & $2.80 \pm 1.60$ & 9.97 & 63.10 & $\boldsymbol{\bullet . 0 7}$ & 2.1 \\
\hline 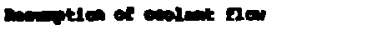 & - & - & - & - & - & - & - \\
\hline 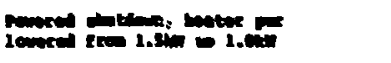 & $3.0=10-1$ & $1 . n=10^{-2}$ & 22.6 & 28.06 . & 32.26 & 6.5 & 2.6 \\
\hline Im & $\bullet .0=10-4$ & $3.10=10^{-3}$ & 5.30 & 23.40 & Les.66 & 7.01 & 2.4 \\
\hline 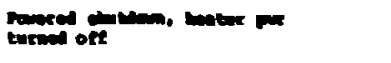 & $1.05=20^{-3}$ & $1 .-4=10^{-3}$ & 2.44 & 5.77 & 111.42 & 6.54 & 1.6 \\
\hline 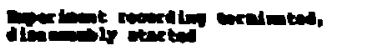 & 一 & - & - & - & - & - & - \\
\hline
\end{tabular}


2hate I (comrnu

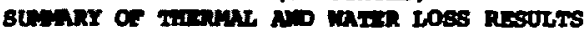

\section{5}

a Byotenatic errors in the penenetica dew-polnt gage data have been corrected. Data taken with the chilled-nirror dempoint gages were not ueed in onleulations of weter lose rates during periods in which the mirrora were fouled.

b Heater powers are celculeted from the seasured heater voltages and currents.

c The location of thermocouple 11 (XC (11) within the alt block is approxiestely $16.8 \mathrm{~cm}$ radially outward fro the block's axis of symetry, along the aldplene of the block. The highest obnerved salt hlock tenperstures wre neneured on this gege. The temperatures listed here are equilibril temperatures that are reached aproxinately three day following changes in hater poiver of boundary temperatures.

The maximu temperature manured on the surface of the heater by either themocouple 5 (ot lou hater power levels) or thermocouple 6 (at high heater power levelef is shown In this colum.

- This temperature is calculated for a poittion along the aidplane of the aalt block, $2.5 \mathrm{~cm}$ radlally imard from $\mathrm{xC} 111$. This is at the surface of the hater borehole adjecent to the cruabed salt beckfill. The calculation abues cylindelcel symetry and no axial component of heat flux; it sinply extrapolates the $2 \mathrm{Cll}$ temperature radially inward.

f The thernal gredient is calculated at the position of the temperatures in colvan six. Note that this is in estinate of the maxinum grediant expected on the bocebole surfece and that the thermal gradient over nost of the borehole aurface is nuch waller.

I The wter wolved is deternined wing the durpoint ange data (except for the last three entries). The interval bogin with the tine of the event noted and laste for two days.

h The wter wolved is deternd ned weing the deslccant canleter athod (except for the firat entry). The Interval beglns wth the tine of the event noted in the elret coling and concludes wth the time of the next event listed in the first colun.

1 The wter lose rate follouing the aproxisately 40 -ilinute heter power fallure on Janumy 9 excended the nesaured rate listed, The neasured rate reflect the fact that the ges $\mathbf{f l o w}$ gratem output 1 eg becane saturoted with reepect to mater at roon temperature.

I The two vine listed for the $1.5 \mathrm{kH}$ heting phace refer to temperatures or heat flunes datecridned at the boginuing and at the end of the phase, respectively. The increase in there quantitice with ties is des, in part, to the increase in the average coolant temperature a well as the decrease in the ont' thernel conductivity. 
zine $\mathrm{kx}$

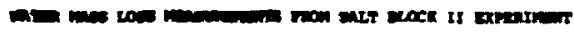

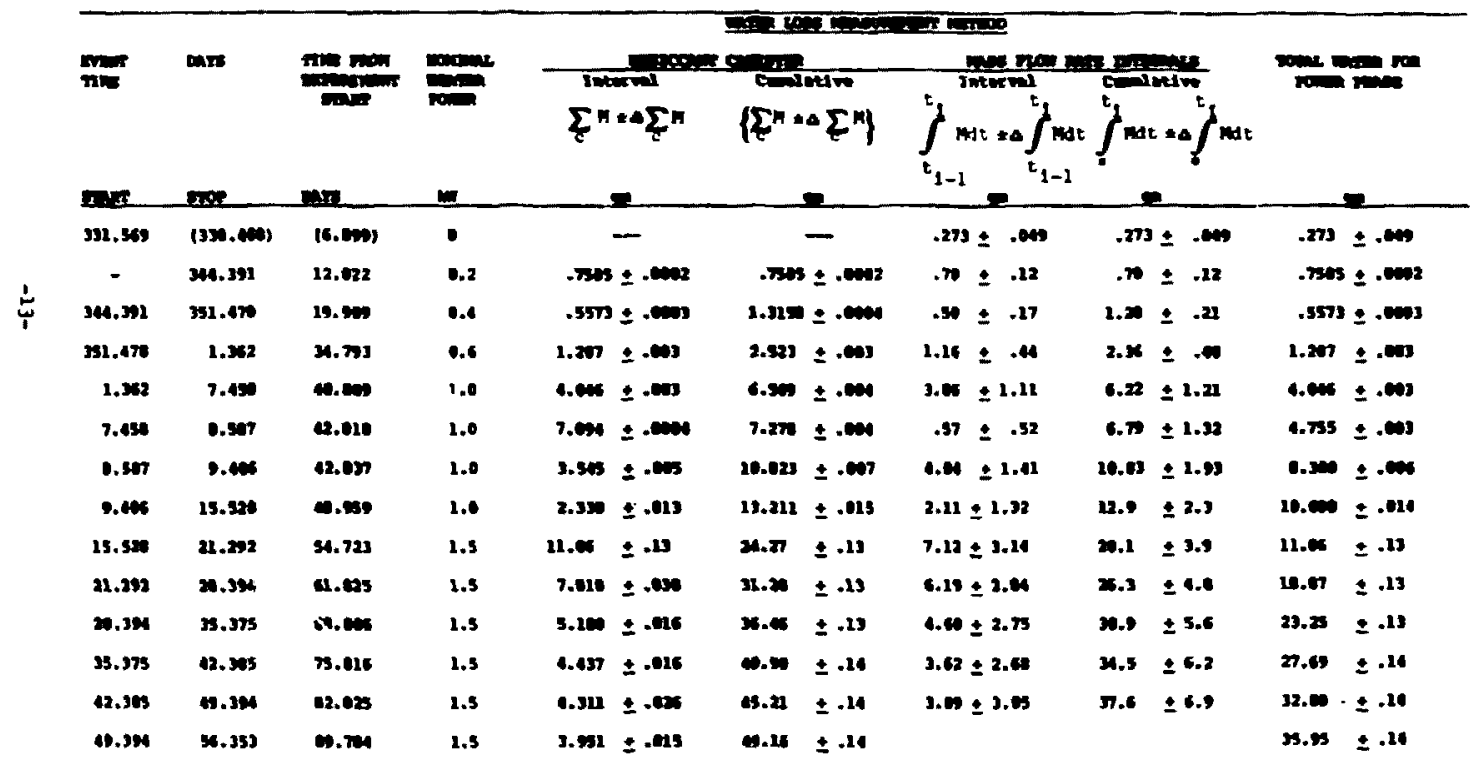


Thire II (Comprosto)

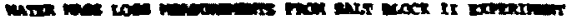

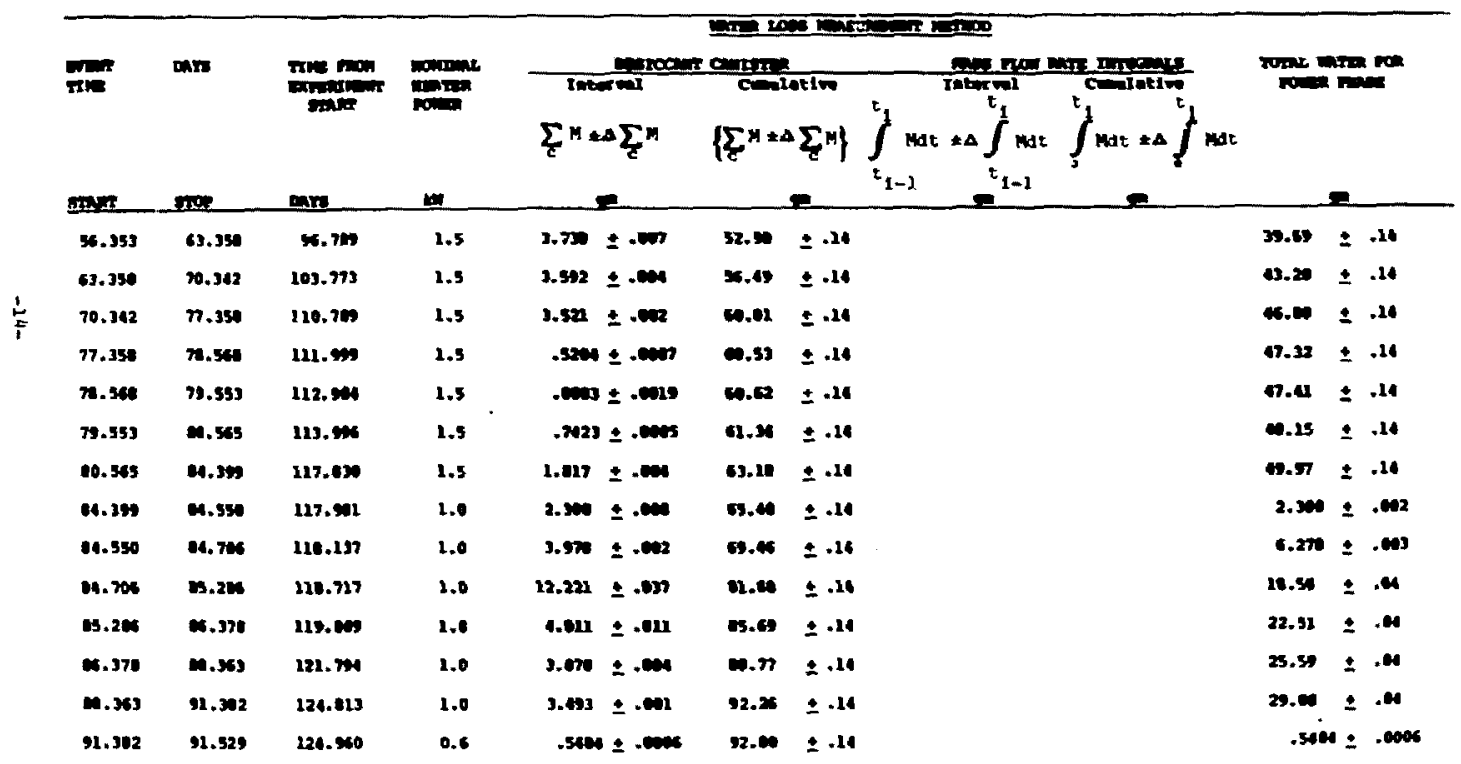




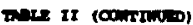

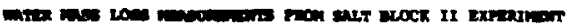

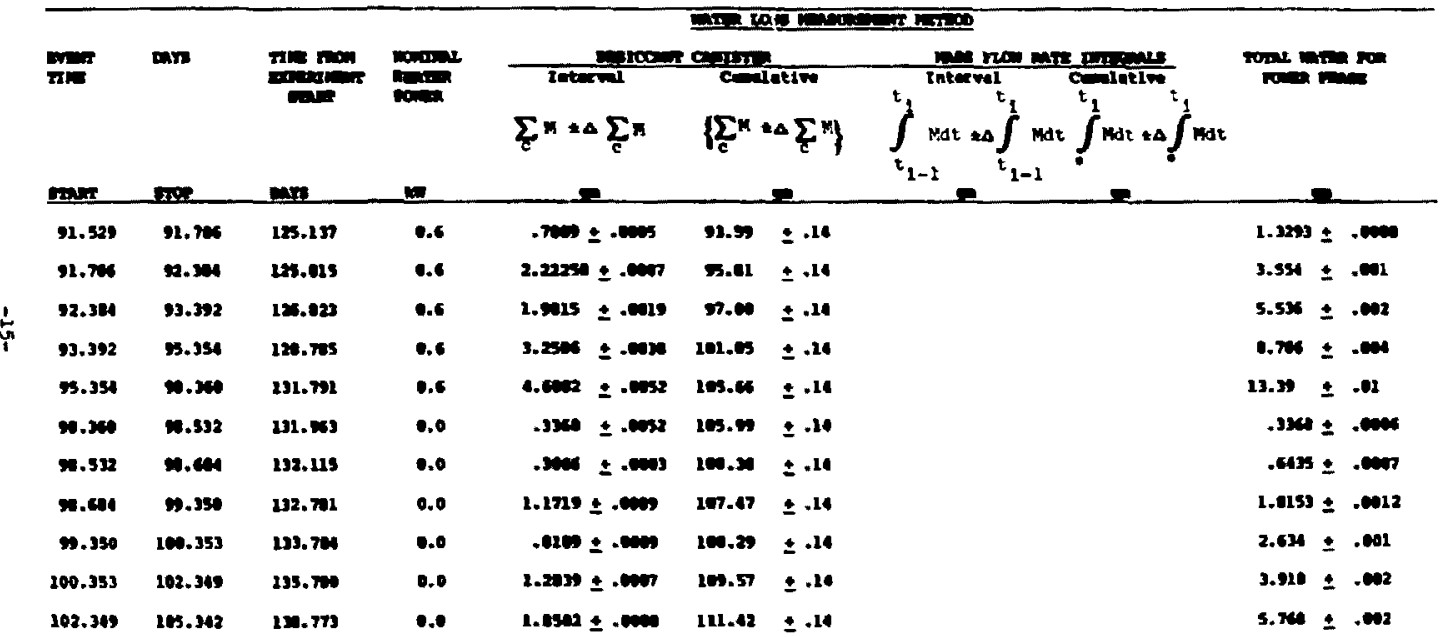


integrals are calculated from estimates of the uncertainties in the flow gas's measured dew points, absolute pressures, volume-flow rates and temperaturos. The systematic error in the Panametrics brand dew point gage data has bren corrected. The data taken with the chilled mirror dew point gages weren mo used in colculations of water mass loss rates during perfods in which the mitrorn were fouled.

Watnr 108 s measuroments made using desiccant canisters to absorb water Erom tive nitrogen 5 low gas stream are tabulated in Table II. For these water. mass measurements, the error shown is due only to the estimated uncertainty arising from ighing the canisters. It includes no contributions which may ardsn from systematic incomplete or inadvertent water absorption. Figure 4 comparns the sets of water mass loss results for the times up to Fehruary 19 in which hoth woter mass measurement methods were used. In most instances, good agreement within the limits of error is show.

That portion of the Salt 3 Jock II experinent of maximum curation at constant heater power was the $1.5 \mathrm{kw}$ heating phase thot lasted approximately 69 तays. Except for the initial rise in the water mass loss rete, water relcase during this phase was characterized by a water mass loss rate declining monotonisally to zero. Water mass lose data for this portion of the experiment together with the hest power law functional form fit to 8 of 11 of these rata is shown in Figure 5 .

Nearly half of the water masurad curing the courne of the experiment vas measured during the three-week long heater power shutrown phase. At ench of the three stages of this stepped ceduction in heater power, a relatively large, tine-dependent release of water was measured. In this regard, the hehavior of the salt Block II experiment was similar to that of heated, I kg samplons of geologic salt that were neasured earlier. ${ }^{3}$

One of the more striking features of the water transport measured during this experiment is its highly variable time-dependence. In general, significant, rapid changes in water mass loss rates were observed only after the heater power was changed. For each heater power change the numerically smoothed measured water mass loss rates for the six-day period following the heator power change are shown in Eigures 6 through 15 . The behavior of the water mass loss rate at the start of the experiment and following each 


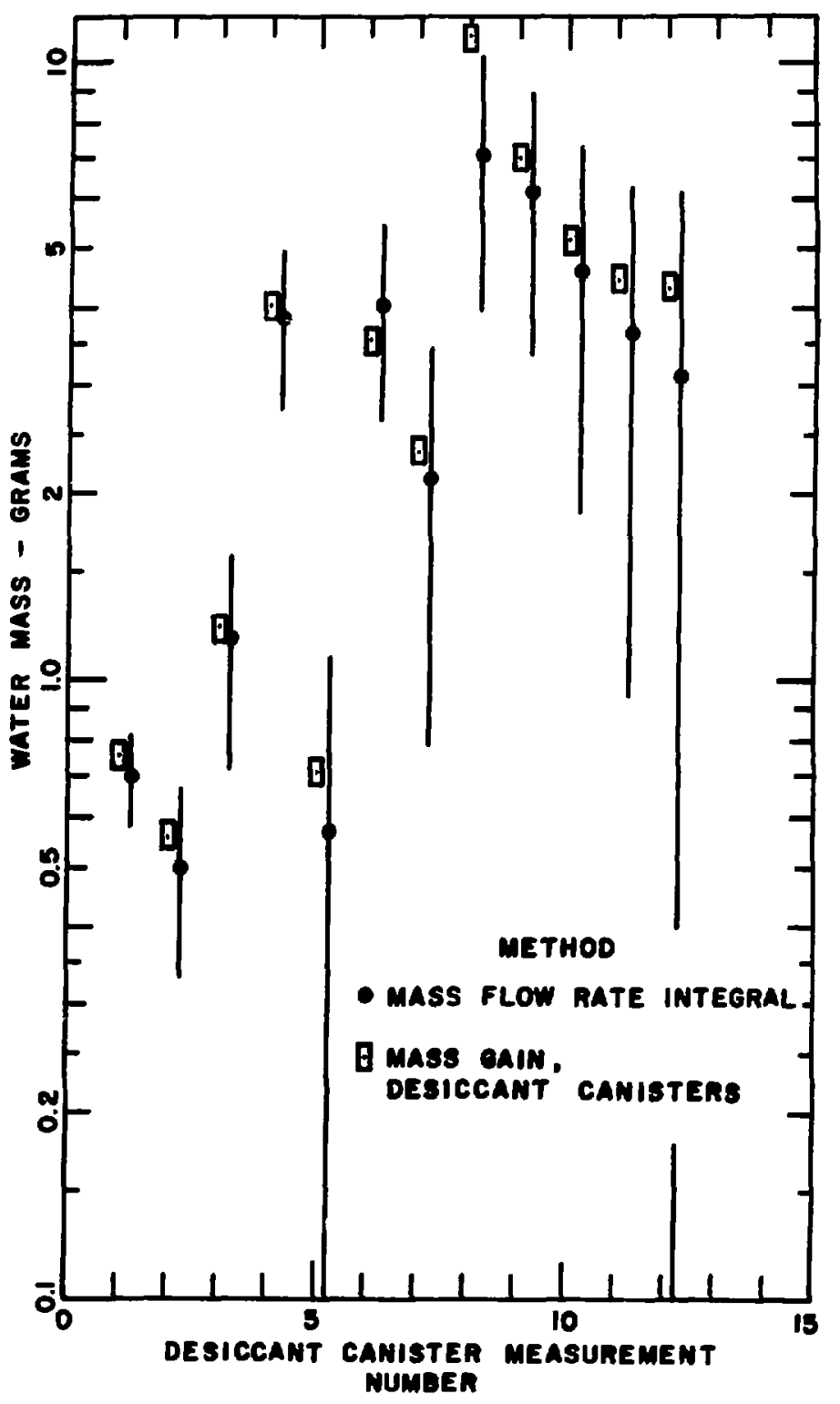

mizure 4. COMPARISON OF TWO WATER MASS LOSS METHODS FOR SALT BLOCK II EXPERIMENT 


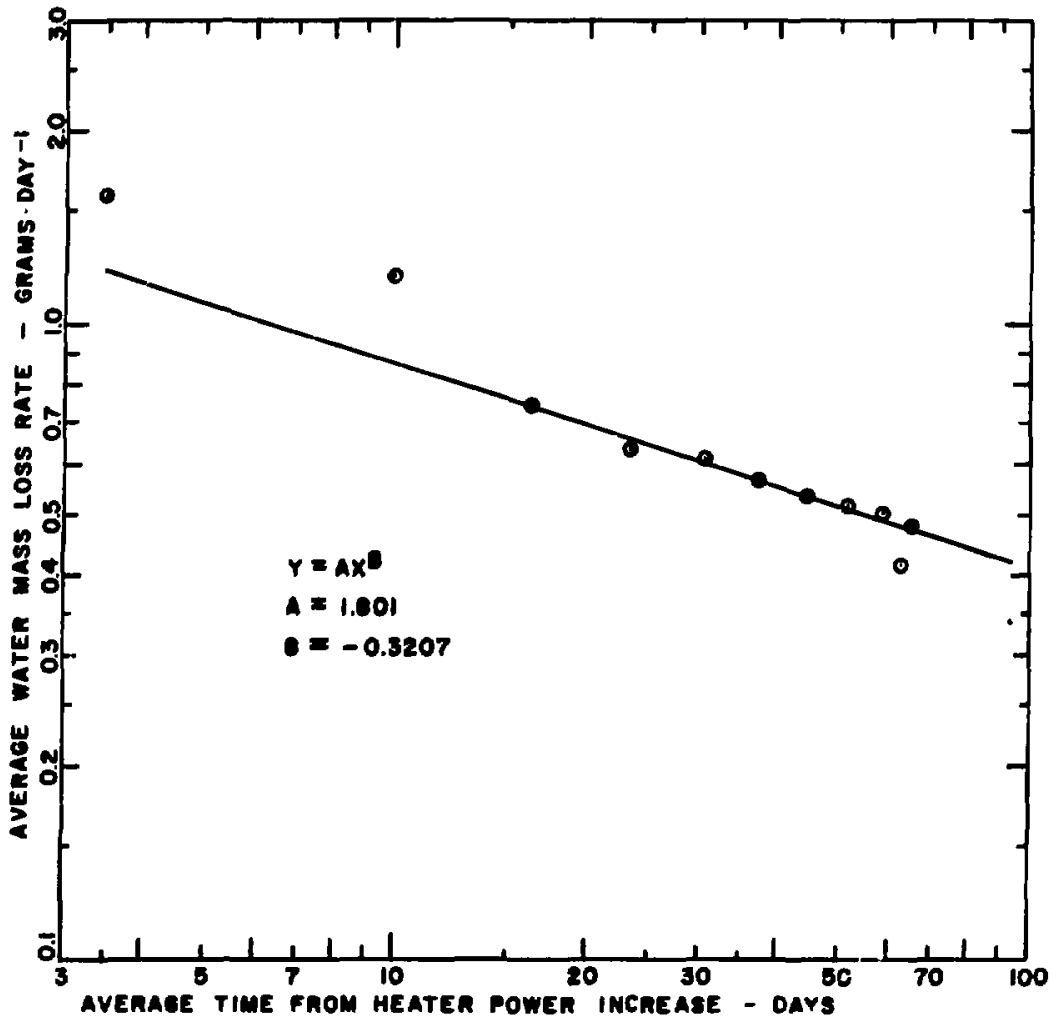

FIgure 5. AVERAGE WATER MASS LOSS RATE FOR $1.5 \mathrm{~kW}$ HEATING PHASE 


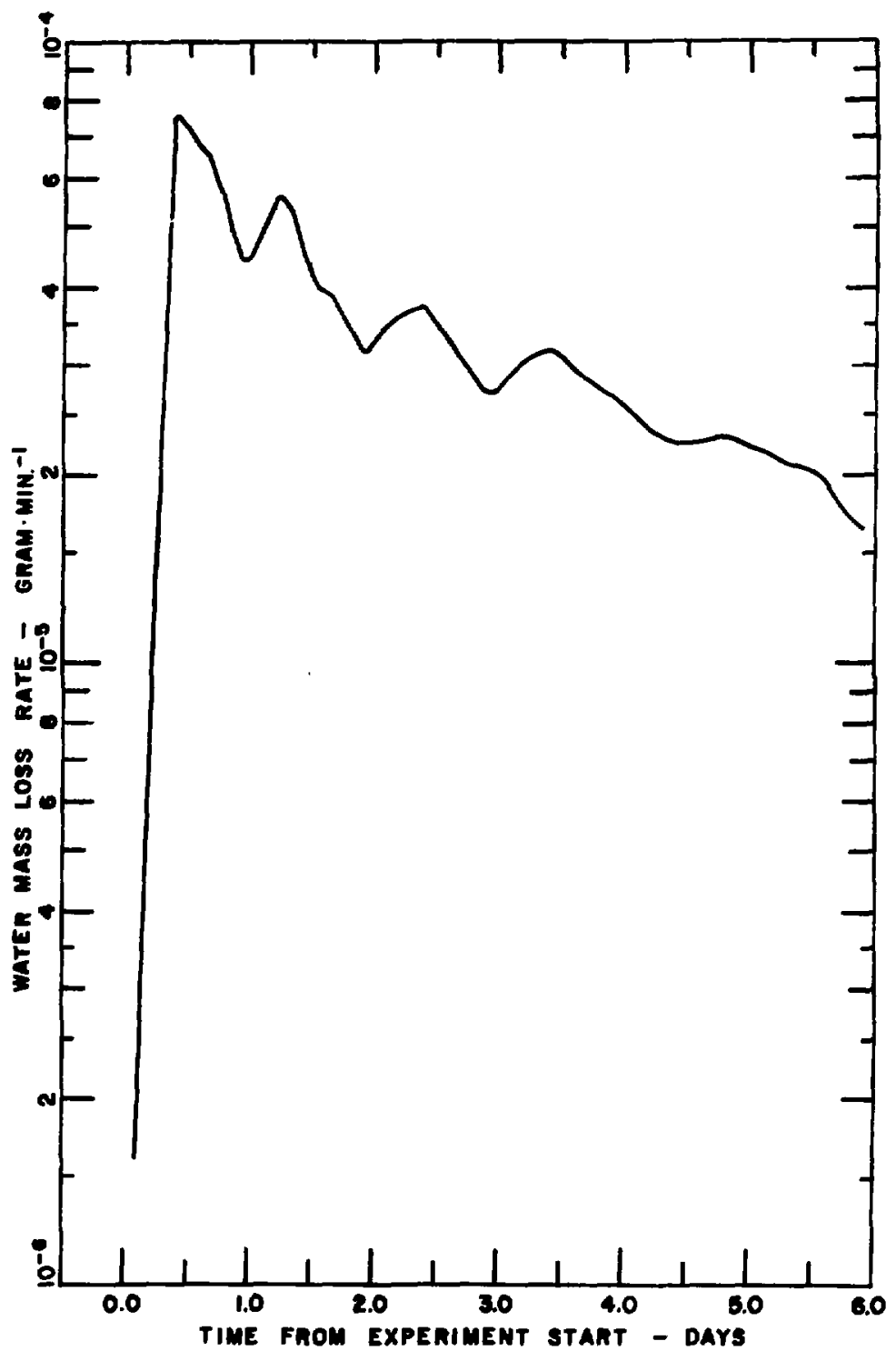

Figure 6. WATER RELEASED AT START OF EXPERIMENT -19- 


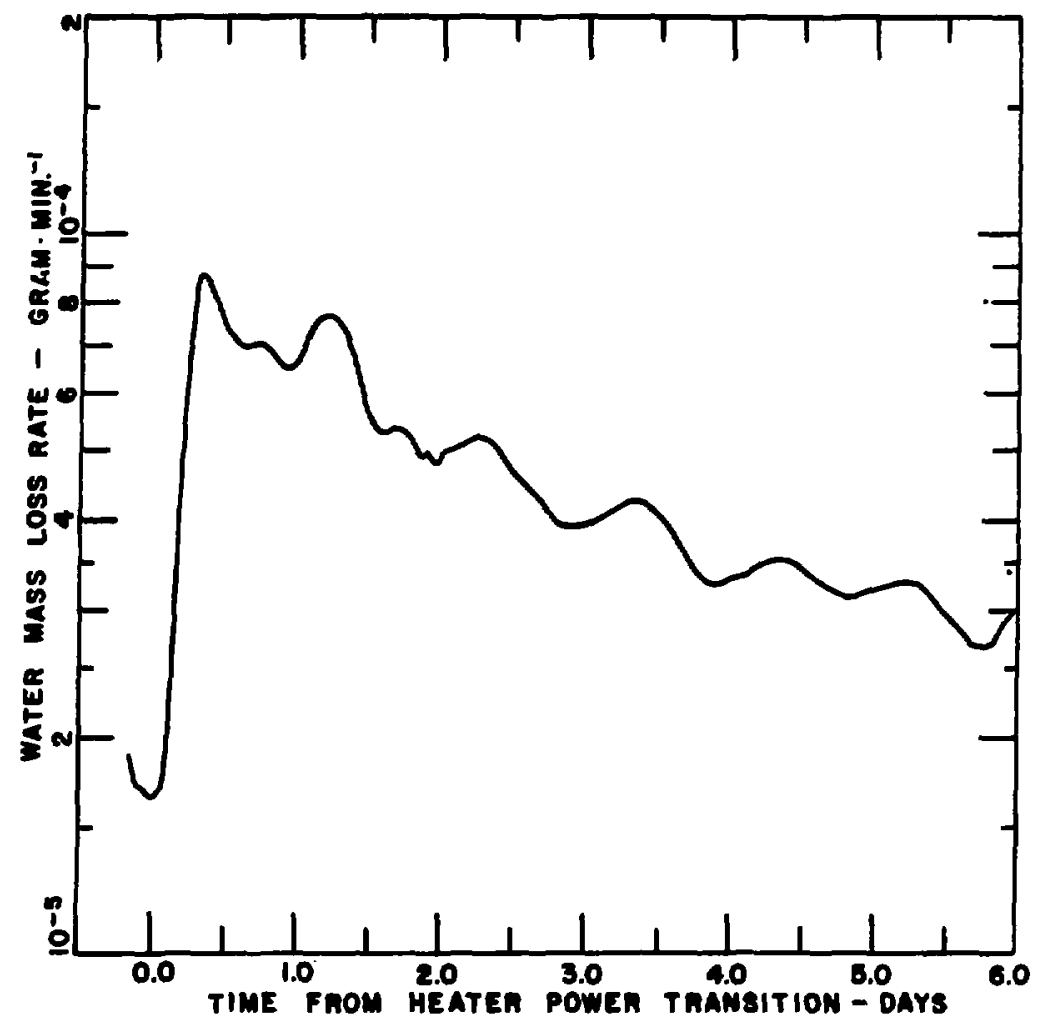

FIgure 7. WATER RELEASED AT START OF $0.2 \mathrm{~kW}$ HEATER POWER PHASE 


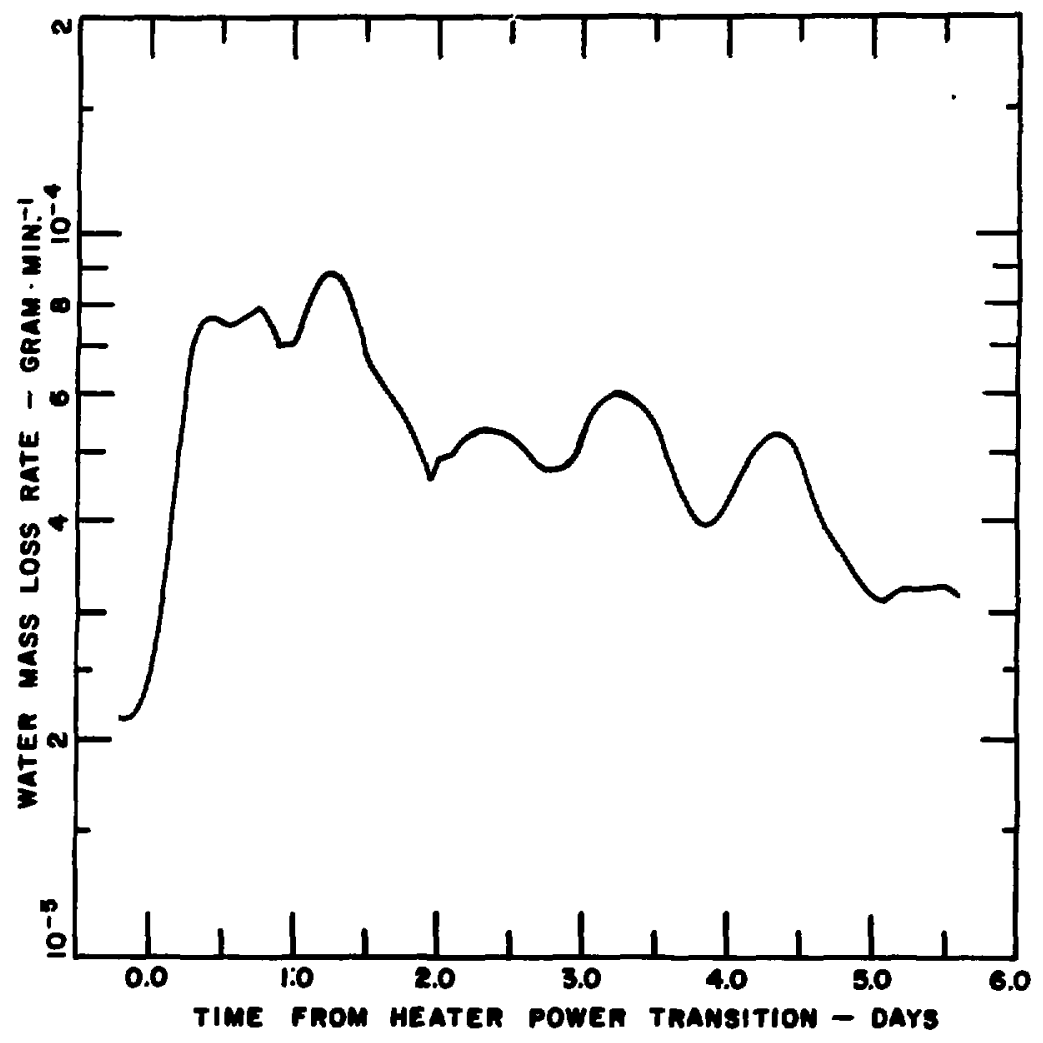

Firure 8. WATER RELEASED AT START OF 0 . i $k !$ HEAT'ER POWER PHASE 


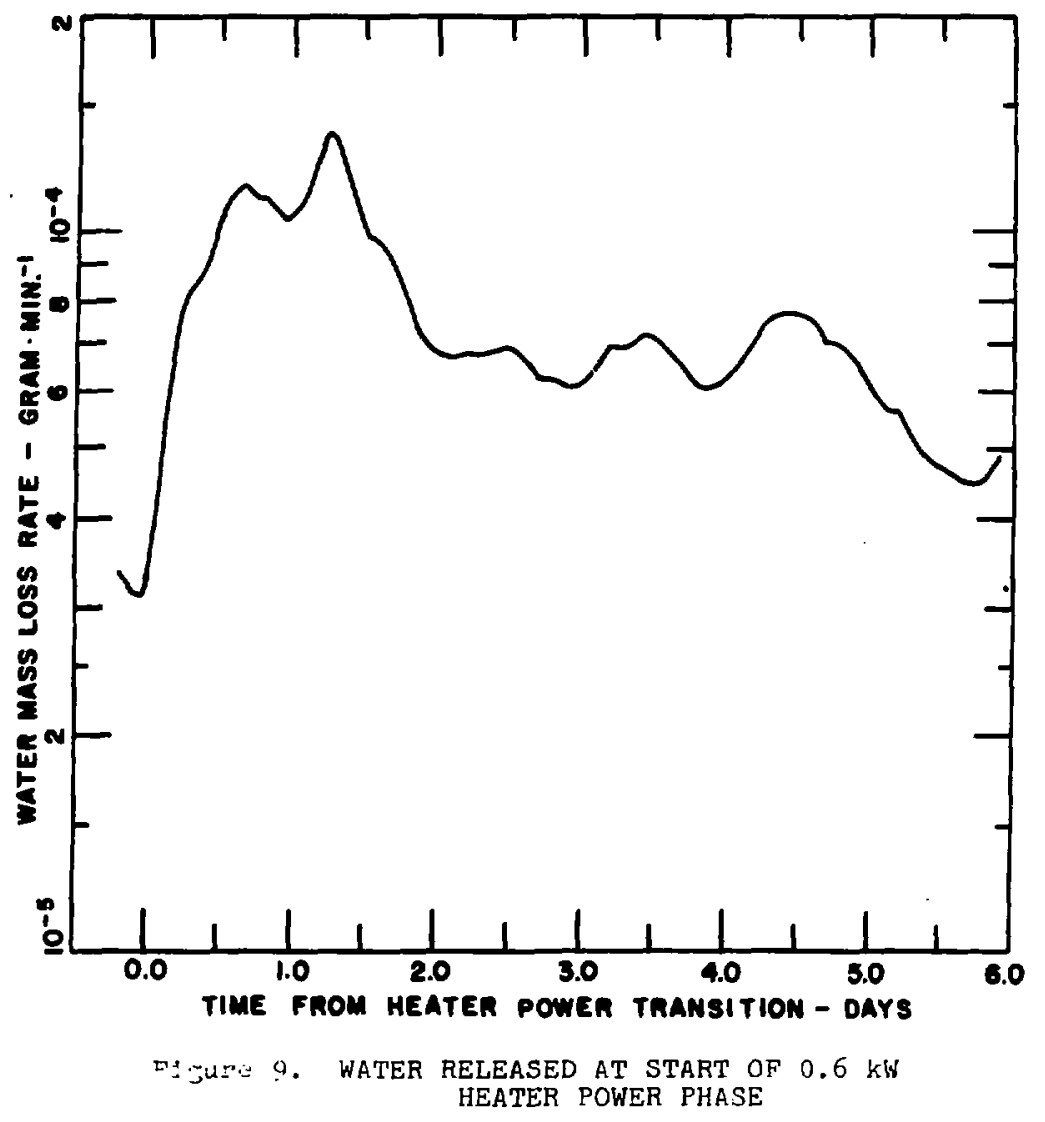




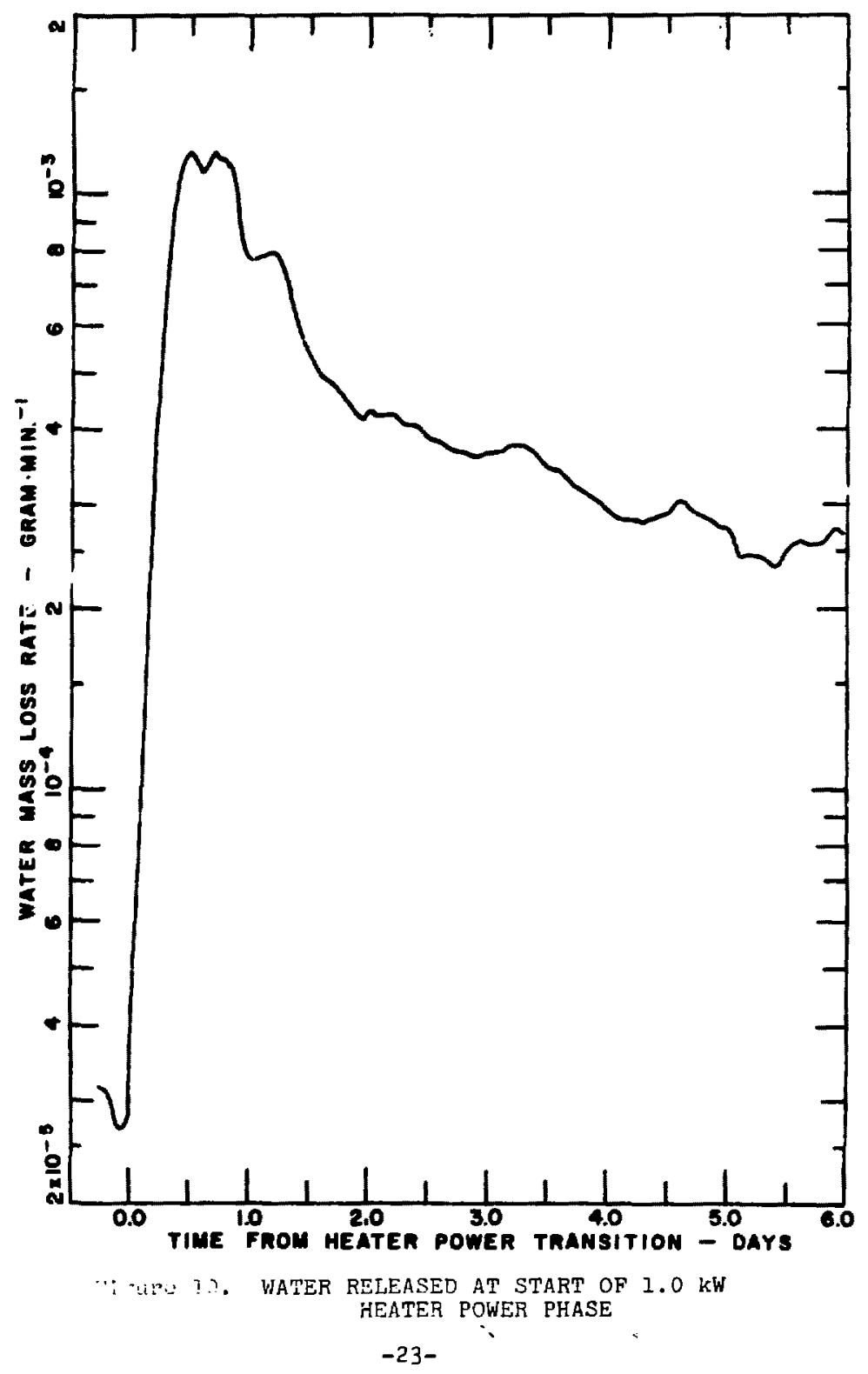




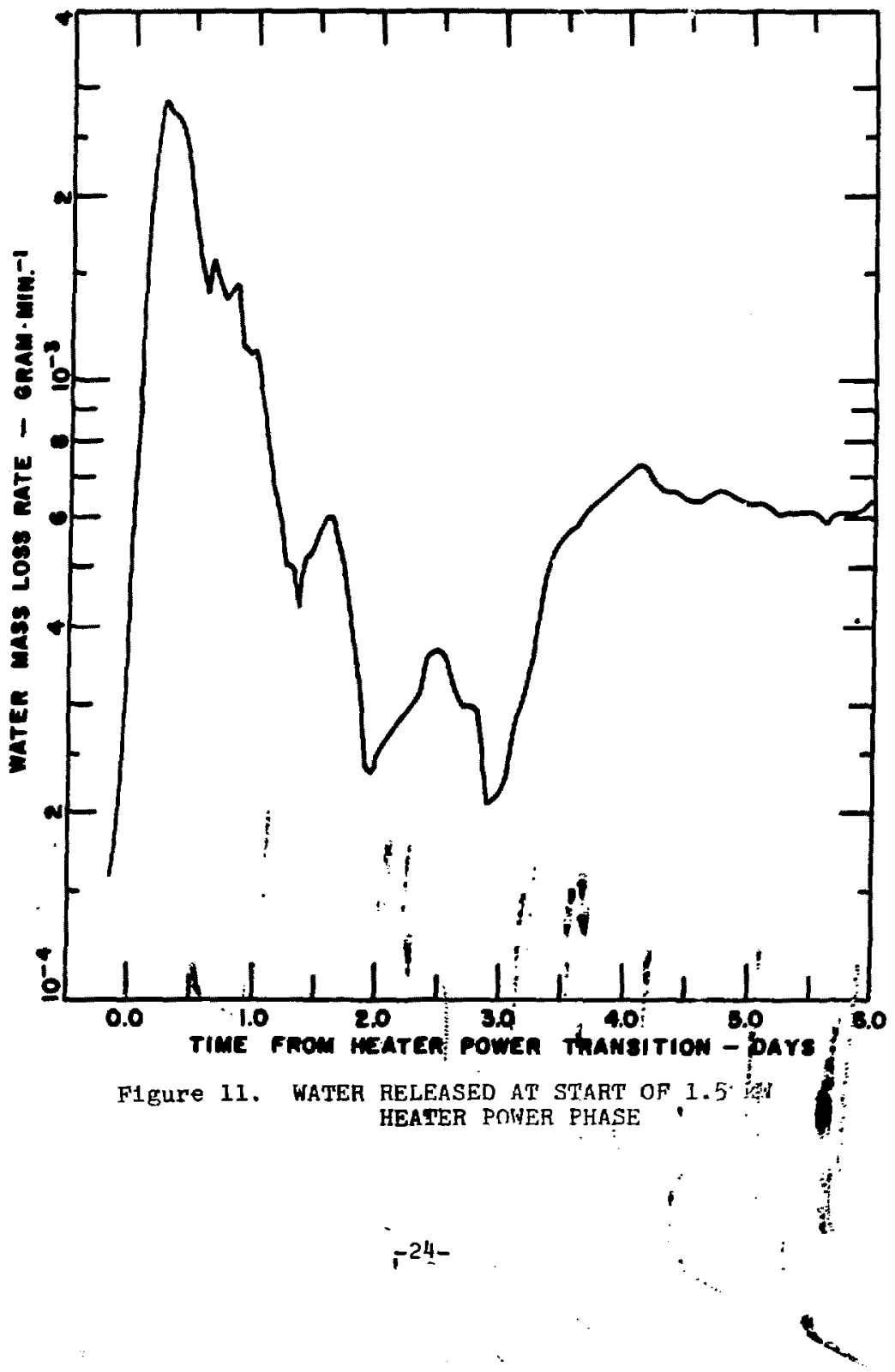




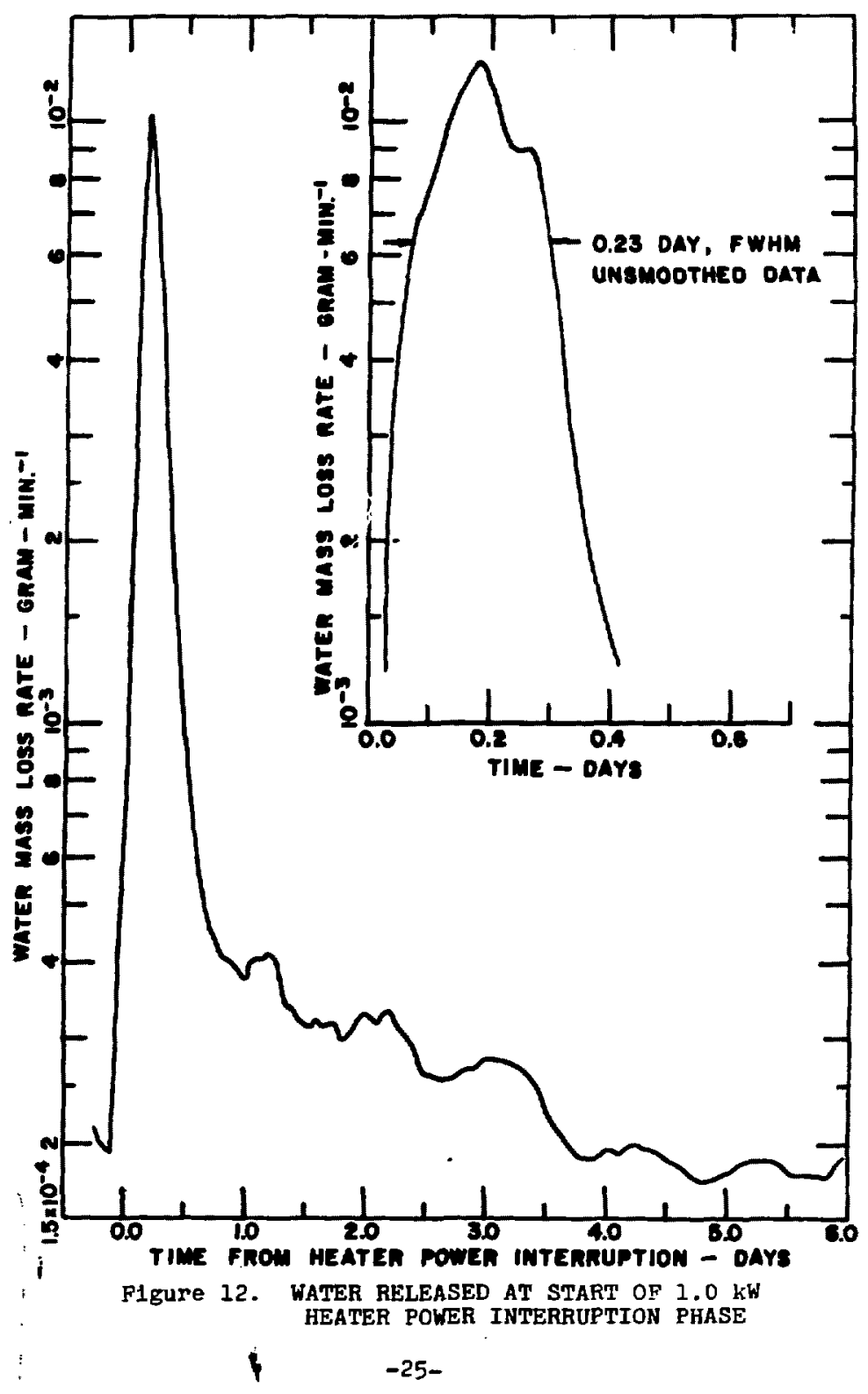




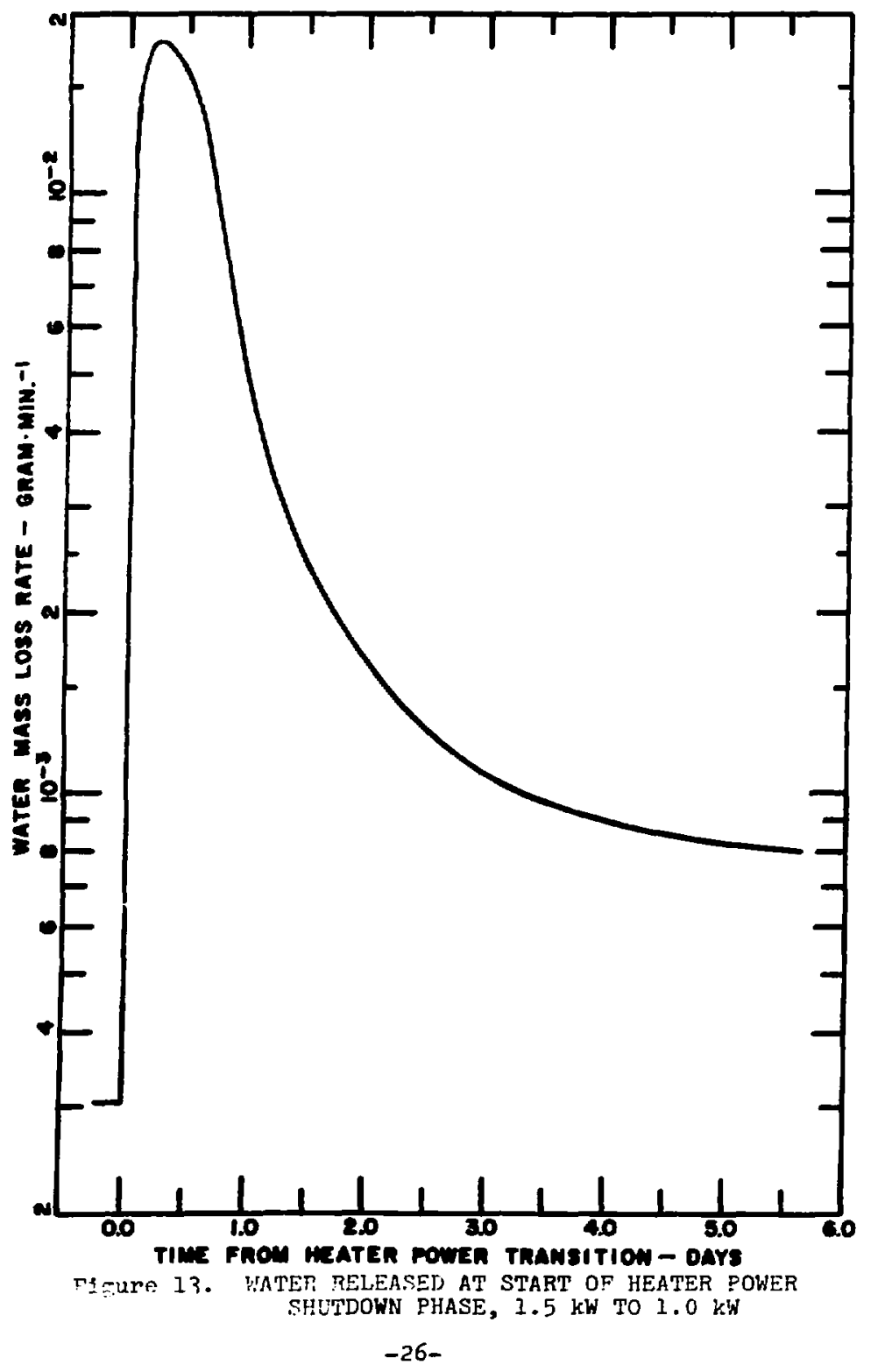




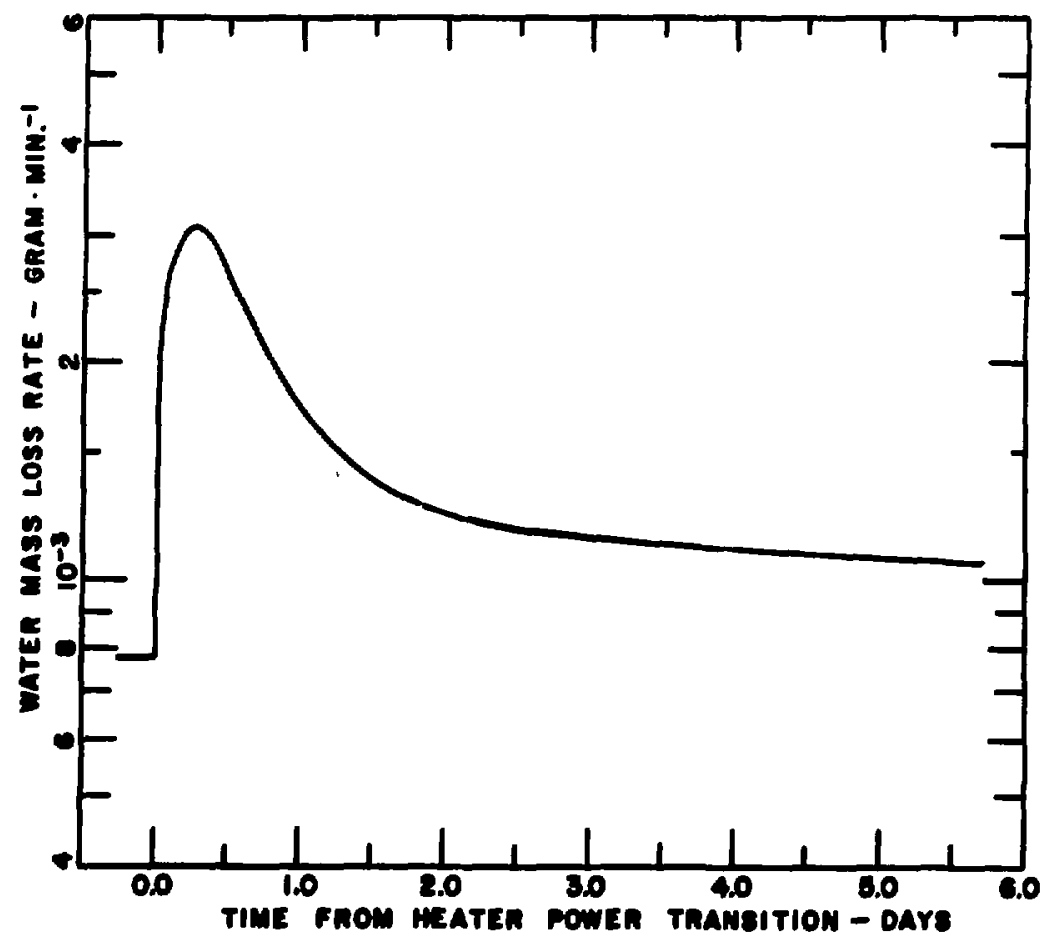

Figure 14. WATER REIJEASED AT START OF HEATER POWER SHUTDOWN PHASE, $1.0 \mathrm{~kW}$ TO $0.6 \mathrm{~kW}$ 


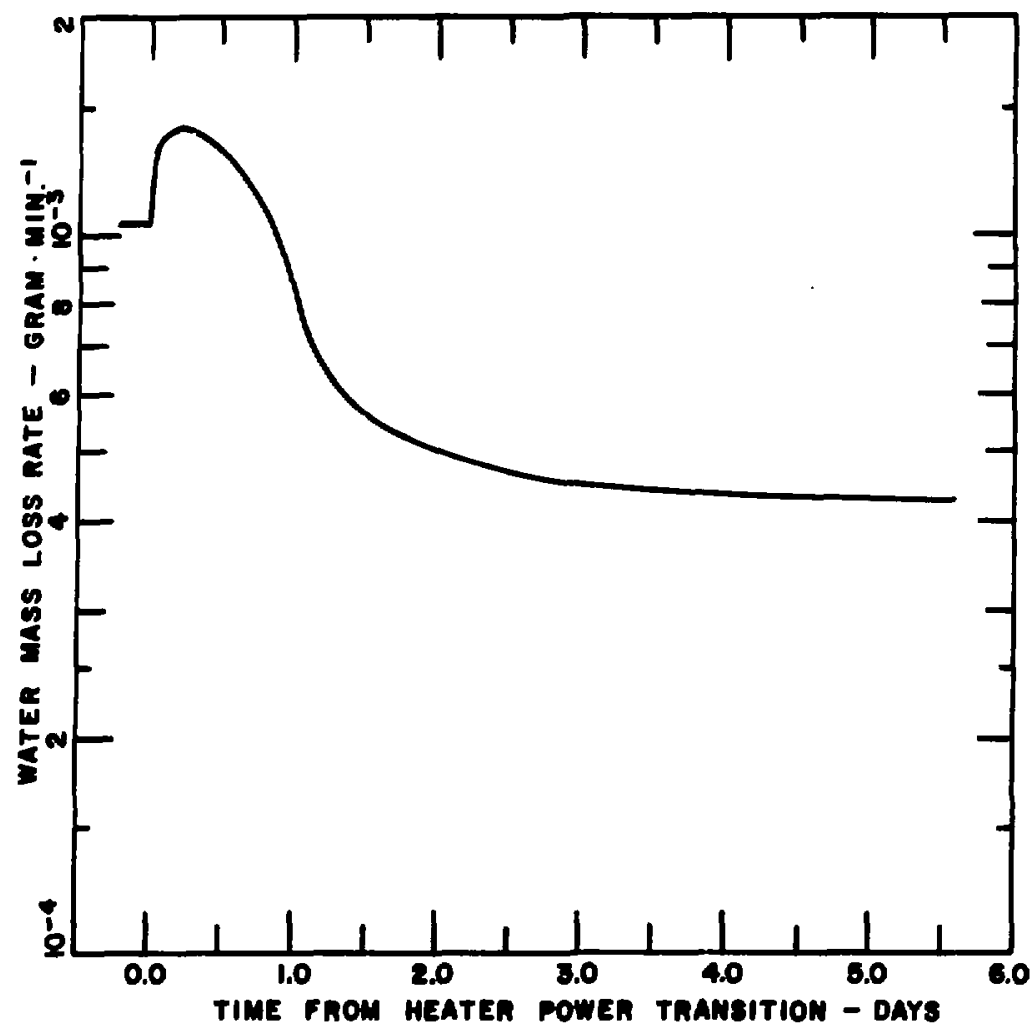

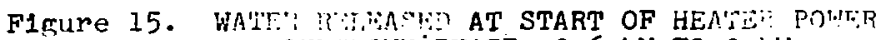
TIMON PHASE, $0.6 \mathrm{~kW}$ TO $0 \mathrm{kH}$ 
of the five abrupt increases in heater power (Figures 6 through 11 ) are qualitatively identical. At the beginning of each one of these events, the water mase loes rate increased over a period of about 0.3 day by approximately a factor of ton. The unter wana lose rate reached a maximun within 1.0 to 1.5 days after the start of each event, and then it declined slowly and monotonically (except for what appeare to be a diurnal effect related to the rise of the eslt's enelosure tomperature with incident colar radiation). For these aix evente, the avarage time for the weter mas lose rate to decline from ite maximun to hale ite maximu le 1.2 days. The average time for this rate dacline is longer (1.8 daye) for the three lowet hater power levels than it is for the three higheat power levels (0.66 days).

Qualitatively, the water ace lose rate following a decrease in heater power is different from the meter mass loss cate following an increase in heater power. The best exaples of this phenomenon are presented in Figures 12 and 13 which show, renpectively, the weter ase lose rates following the heater power interruption at $1.0 \mathrm{kH}$ and following the heater power shutdown from $1.5 \mathrm{kH}$ to $1.0 \mathrm{kH}$. In thece evente following a decrease in heater power, one observes a nudden increase in the mter ans loss rate by about a factor of 50. This is a tranaient phenomenon and is followed by an abrupt decline in the unter wase lose rate. The mter ane lose rate "pules" shown in Flgure 12 has a full width at halt maximo of 0.23 days. Figure 13 shows a sonewhat wider pulse, but these date axe langthened in ties because they were determined at time average rates using the desiccant canister mesurcinente.

Water mase lose as a function of time for the duration of the experiest 1. presented in Figure 26. Data bhom here include the continuous dew-point gage results edjusted to agree with the deniccent canister results at those times for which both measurements were avallable. Figure 17 shows a "amoothed" wher ans lose rate curve for the duration of the experisent. Here the total wtor ane date (Figure 16) tabulated at 0.5 day intervals was differentiated numically to provide these cates, consequently peak "average" rates in this figure are less than the pask rates shom in Figures 6 through 15.

Prior to the astenbly of the solt Block II experiment, enteples mere removed from the ealt cylinder'" upper surfuce and analyzed for their water content by measuring their ases lose upon bating to 2500C. Following the 


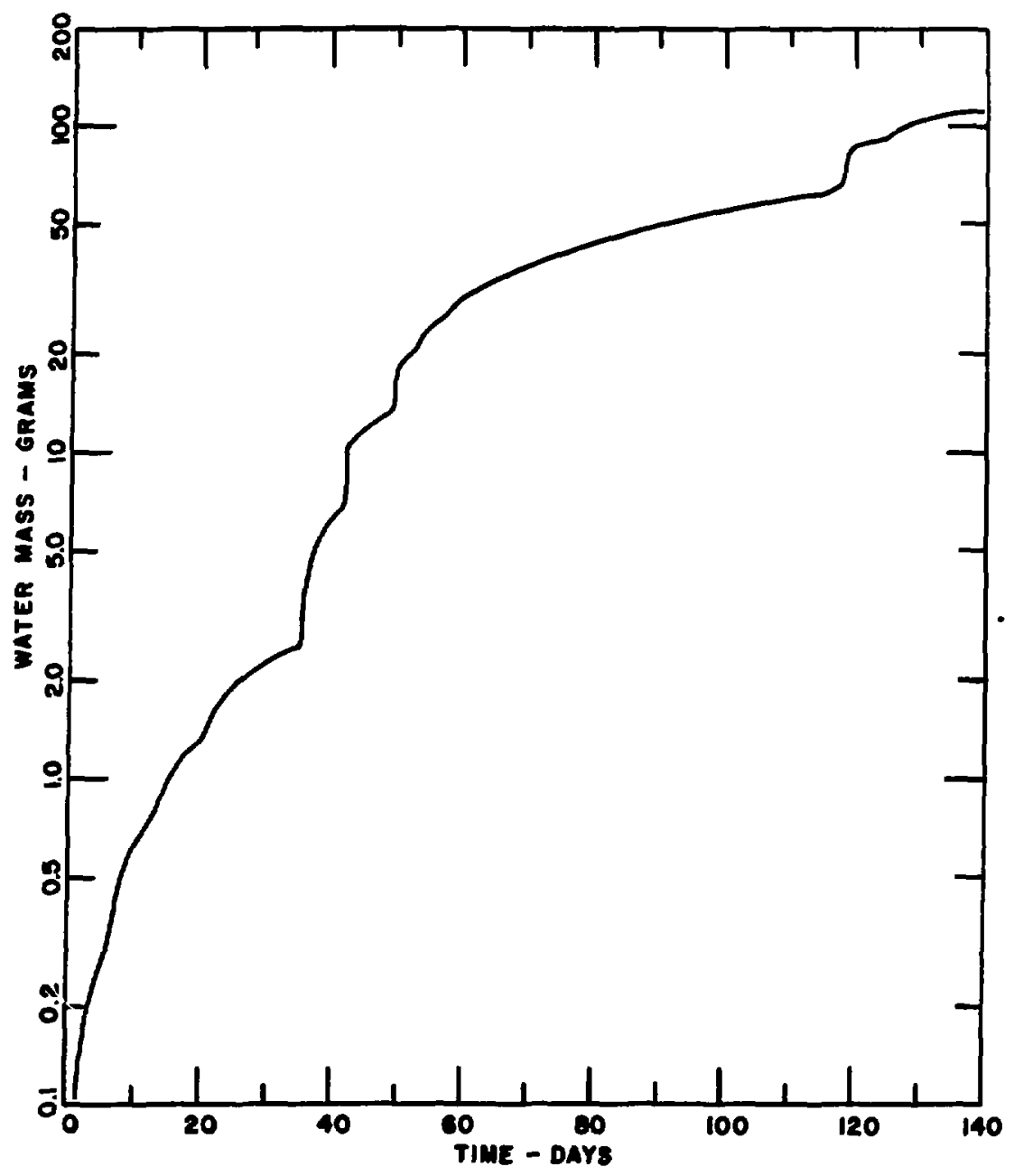

F1gure 1.6. WATER RELEASED IN HEATED BOREHOLE REGION 


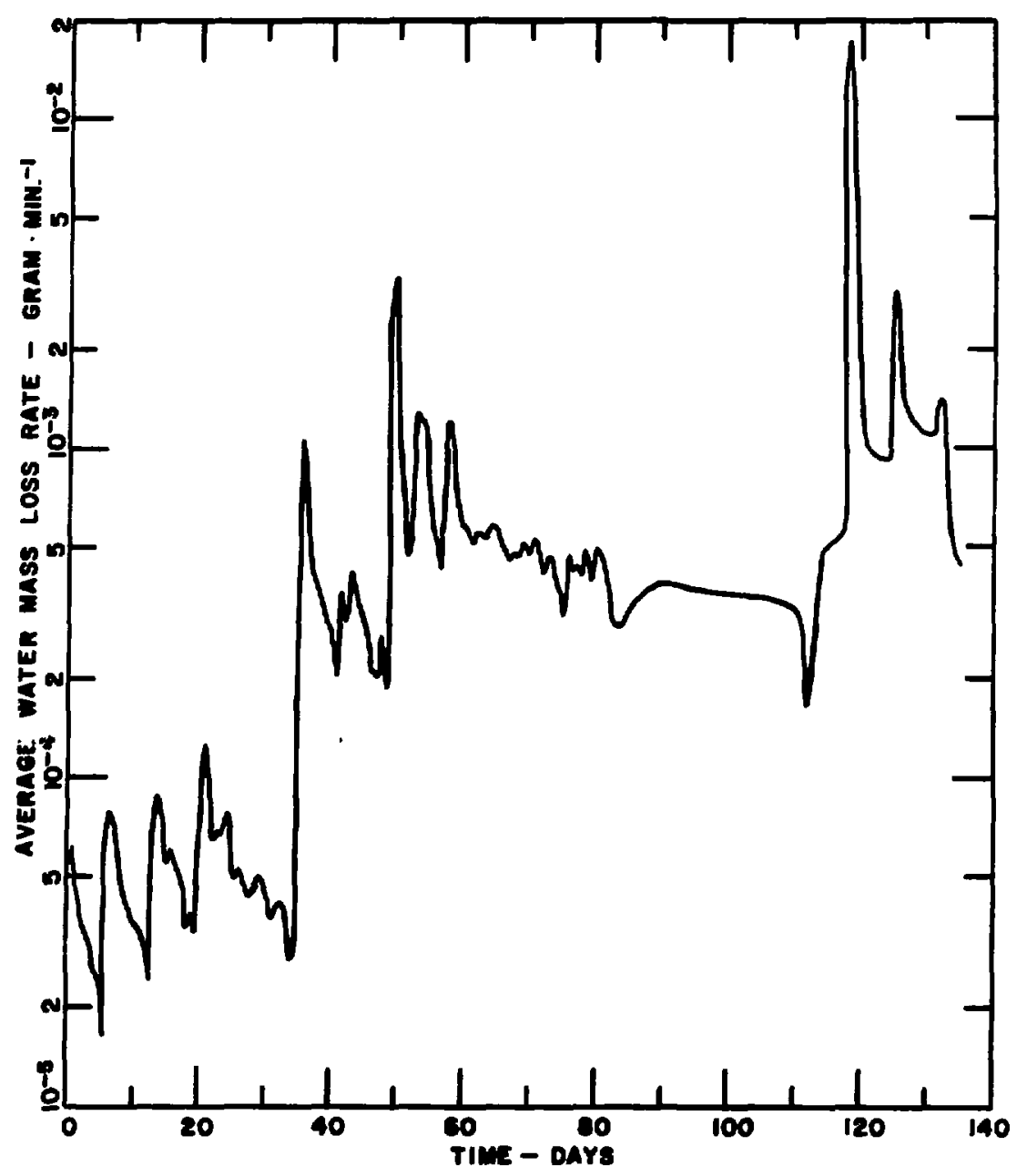

Figure 17. WATER RELEASE RATE IN HEATED BOHEHOLE REGIMI 
experiment's disassembly, two sets of samples were taken from the salt block anc were analyzed for their water content using the same water-analysis procedure. The purpose of these measurements was to determine the post"xpreiment spatial distribution of water within the salt block, and if mistinle, to relate changes in this distribution from the pre-experiment water Aistribution to the total amount of water released during the course of the experiment. Samples for the first set were taken at different radiol profitions from the material oxposed by cutting and renoving a $0.3 m-t h i c k$ slah from the tnp of the salt blsck. The process of removing the samples from the tent biock exposed then to an uncontrolled post-teet environment for approyiinately 40 days prior to their analysis for water content. The samples shrued une xpertedly large uass losses upon heating $10.55 \pm 0.17$ standard error, mass prrent. 1. The second set of samples ceme from oores which were cut from the silt block following the removal of the 0.3 m-thick slab. Specimens $r$ rom thesn onres were nalyzed within two days following the nores' removal from the olock. specinens from the second set exhibited approximately one-fourth is misch mass 1008 upon heating $(0.143 \pm 0.011$ standard ertor, average mass parcent) as did the specinens from the first set. Specimens from the first sot last more mass, on the average, than did the pre-test specimens $10.125 \pm$ 0.020 standard error, average maes percent): howevar, the overage mass lnss from the recond set of samples agrees, within the limitn of ercer, with the averagn mass loss from the pre-test sanples. The discrepancy between the mossurements from the two post-test sets suggests that the post-test environment may have altered the water content of the salt samples. The averages of the results for specinens from both sets of post-test samples are shown in Figure 18. It has not been established whether, as shown here, the apparentiy relatively lower average water content of the samples taken from salt closest to the experinent's heater was caused by water loss from the salt block during the experiment.

\section{THEPEAL BEHAYIOR}

The second principal experimental objective was to understand the timedependent theralal behavior of the Salt Block II experiment. 


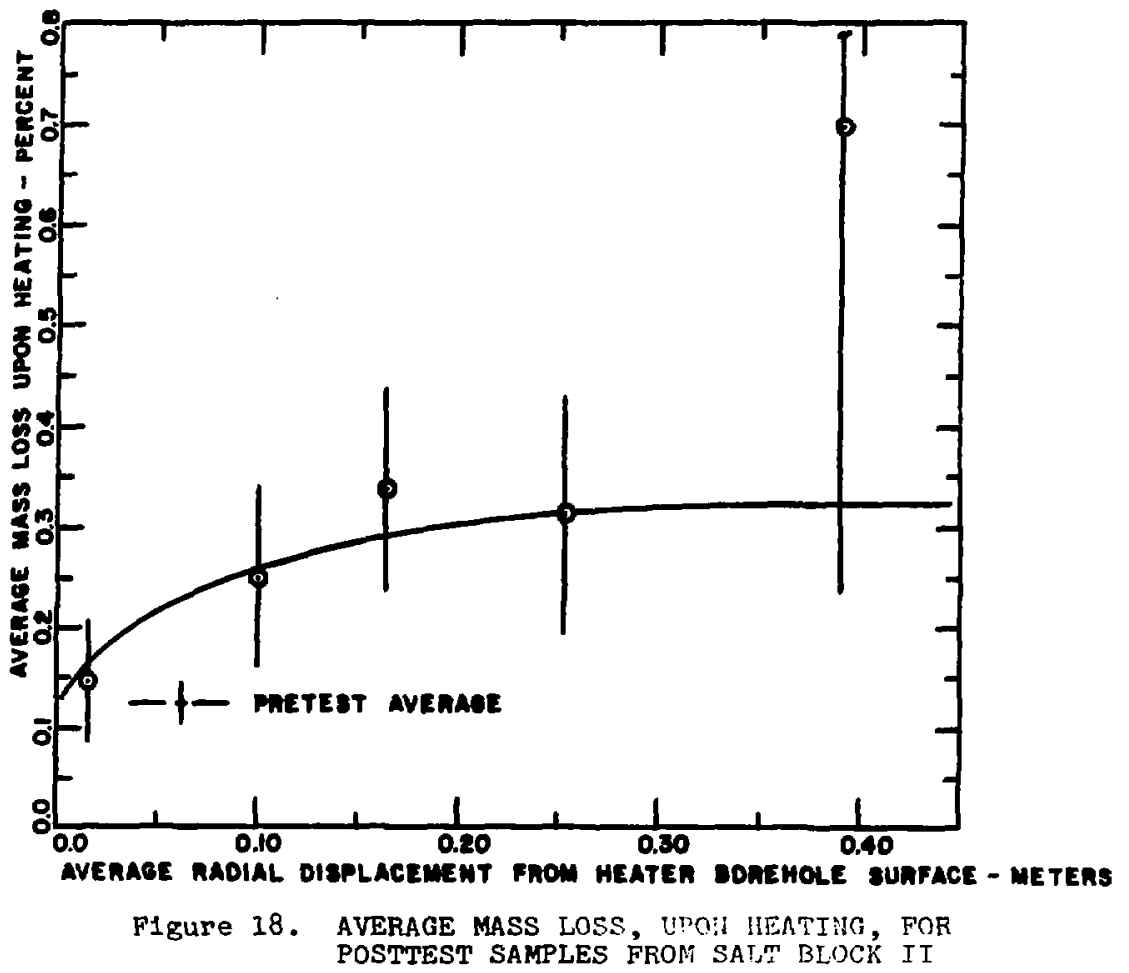


In order to determine temperatures and heat fluxes throughout the salt block for the duration of the experiment, 9 heat flux gages and 39 thermocouples were placed at selected locations within and on the block's cylindrical heater, the salt block, and the salt block's containment vessel, and in the environment surrounding the experiment. The experimental geometry was chosen to provide well-defined thermal boundary conditlons, for these are neceseary if one is to perform any accurate thermal modeling. Figure 19 shows a sectioned, scaled drawing of the assembled experiment and includes thermal nensor locations and relevant dimensions and materials.

Detalled time-dependent thermal calculations were performed by Oscar George (5511), and the final resulte of these calculations are now available. 2 These calculations we performed using approximate times for heater power changes and nominai values for the heater power. A significant result of the experinent is the porer-dependent, non-uniform axial distribution of heater power; a measured, self-consistent set of heater power profiles was used as an input to the thermal modeling calculations.

The power dependent axial variation of temperature within the electric heater was a consequence of its lack of internal baffing as well as its operation at very low power levels. At low electrical power the principal thernal transport mechanien from the heater rods to the heater wall was convection. Conecquently only the upper portion of the heater case was effectively heated. For hater powers in excess of $1.0 \mathrm{kH}$ radiant transport from the heater elements to the heater caes was doninant, and the heater's cesultant tesperature profile was more nerly gretric about its nidplone.

Results of the calculations include best fit values for the thermal conductivity of the salt and crushed salt backfill as well as predicted values of temperature and hent $f$ lux (where appropriate) at each thermal sensor location. Independent calculations of the aalt's thernal conductivity were performed using the masured torperatures and heat fiuxes along the atdplane of the salt block. The two ests of theranl conductivity versus temperature data are presented in Figure 20.

In general, the location of each thermal sensor, agreement between predicted and neasured temperatures is within several degrees celsius, but only a selected sall fraction of all the measured and predicted thermal 


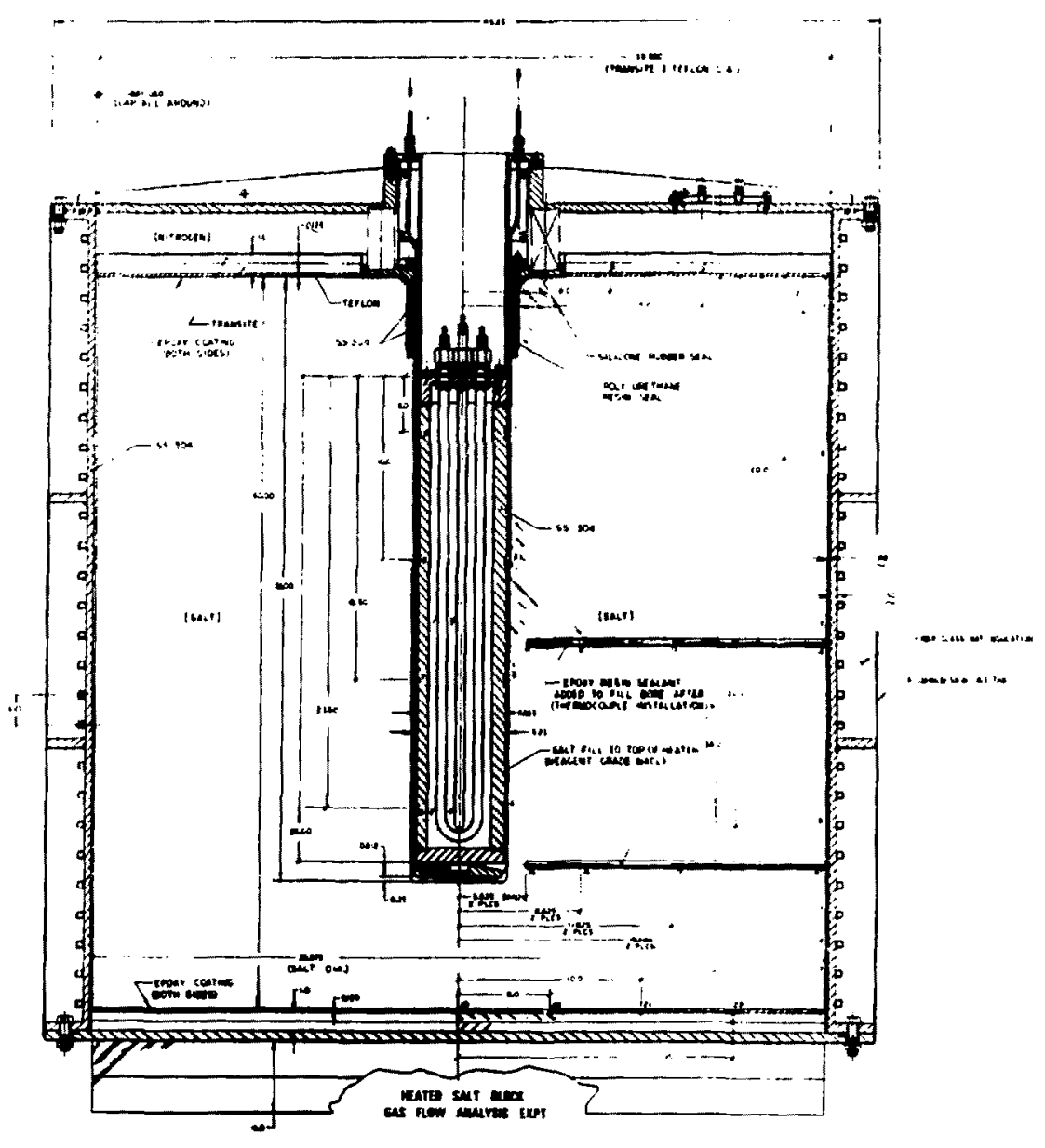

FIgure 19. SALT BLOCK II EXPERIMENT ASSEMBLY 


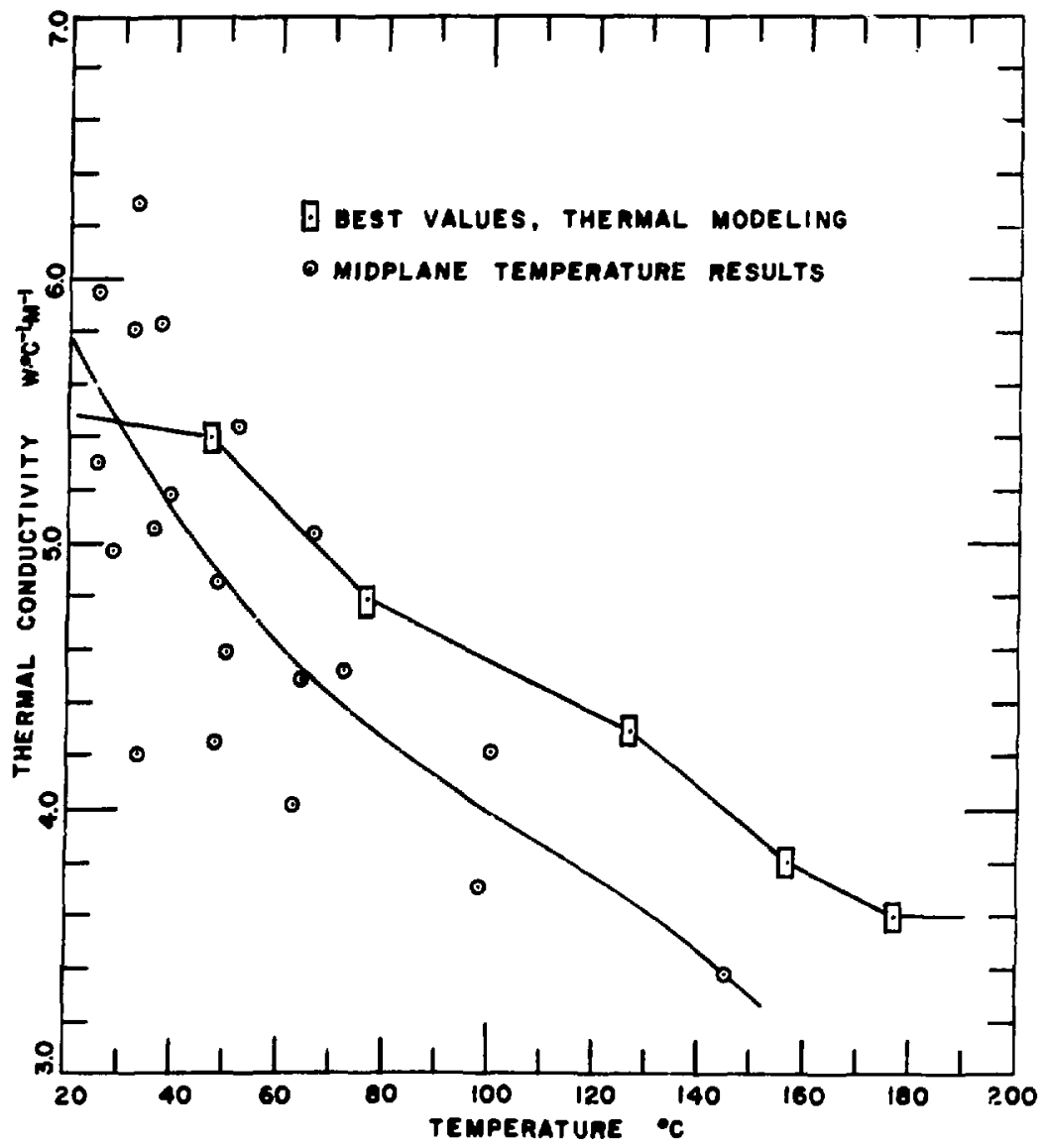

Tigure 20. THERMAL CONDUCTIVITY OF GEOINGIC.SALT USED IN SALT BLOCK II EXPERIMENT 
data is presented here. Figures $21,22,23$, and 24 show the measured and predicted temeratures for the four thermocouples located in the mid-plane of the salt block for the period following the heater power transition from 0.2 to $0.4 \mathrm{kw}$. One result of note here is that the e-folding time* for terrperature is position dependent, although throughout most of the salt block, the e-folding times are approximately 0.5 days. Measured and theoretical equilibrium temperatures as well as e-folding times for the $0.4 \mathrm{~kW}$ heater power level are presented in Table III. Temperatures measured by the 4 thermocouples located along the midplane of the salt block (borehole $A$ ) for the duration of the experiment are shown in Figures 25 through 28 . The calculated equilibrium temperature distribution within the salt block is shown in a scaled illustration for each of the 5 heater power levels in Figures 29 through 33. The temperature shown in each box represents the temperature at the geometric midpoint of that volume within the salt block. From these data, numerical methods can be used to calculate the equilibrium values of both temperature and temperature gradient at any point within the salt block. The data shown in Figures 29 through 33 were differentiated numerically to obtain the radial component of the thermal gradient evaluated at the midpoint of each "cell" used in the thermal analysis. The absolute values of these dota (all radial components were negative) are shown for the 5 heater power levels in Figures 34 through 38.

\section{DATA ANLYSIS}

Data from selected channels frow the H.P. 3052A data acquisition system have been printed to enable a prelininary comarison of the thermal predictions with the measured temeratures. The analysis of the measured waterloss rate is essentially complete, and these data have been presented here. The experimental data recorded on approximately 50 Hewlett-Packard floppy

- The e-folding time is the time it takes for temerature changes at a given location to cone within $e^{-1}$ of the terperature difference hetween the equilibrlum temperatures before and after the time of thermal change. 


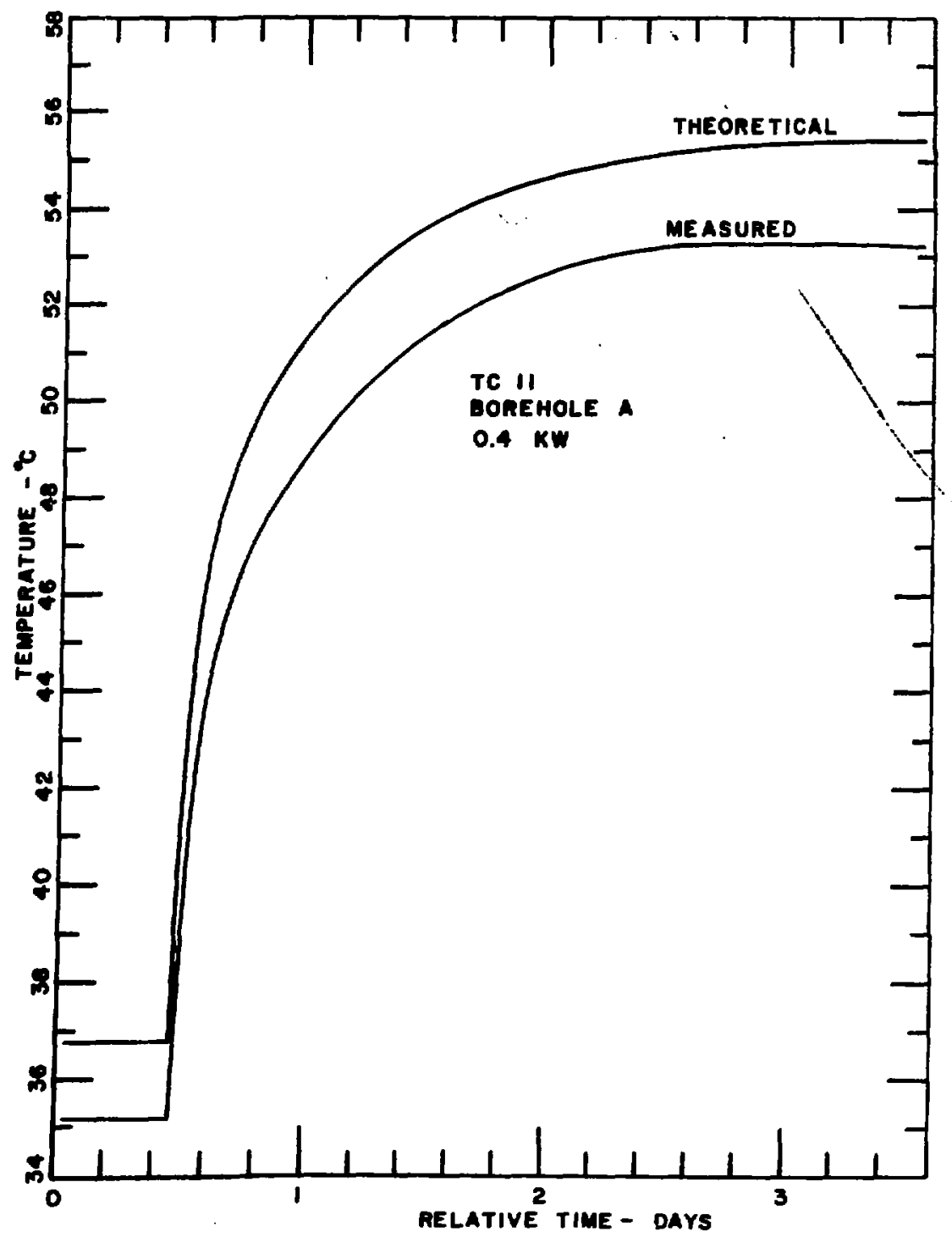

FIgure 21. TEMPERATURE OF THERMOCOUPLE 11 FOR THE HEATER POWER TRANSITION FROM $0.2 \mathrm{~kW}$ TO $0.4 \mathrm{~kW}$ 


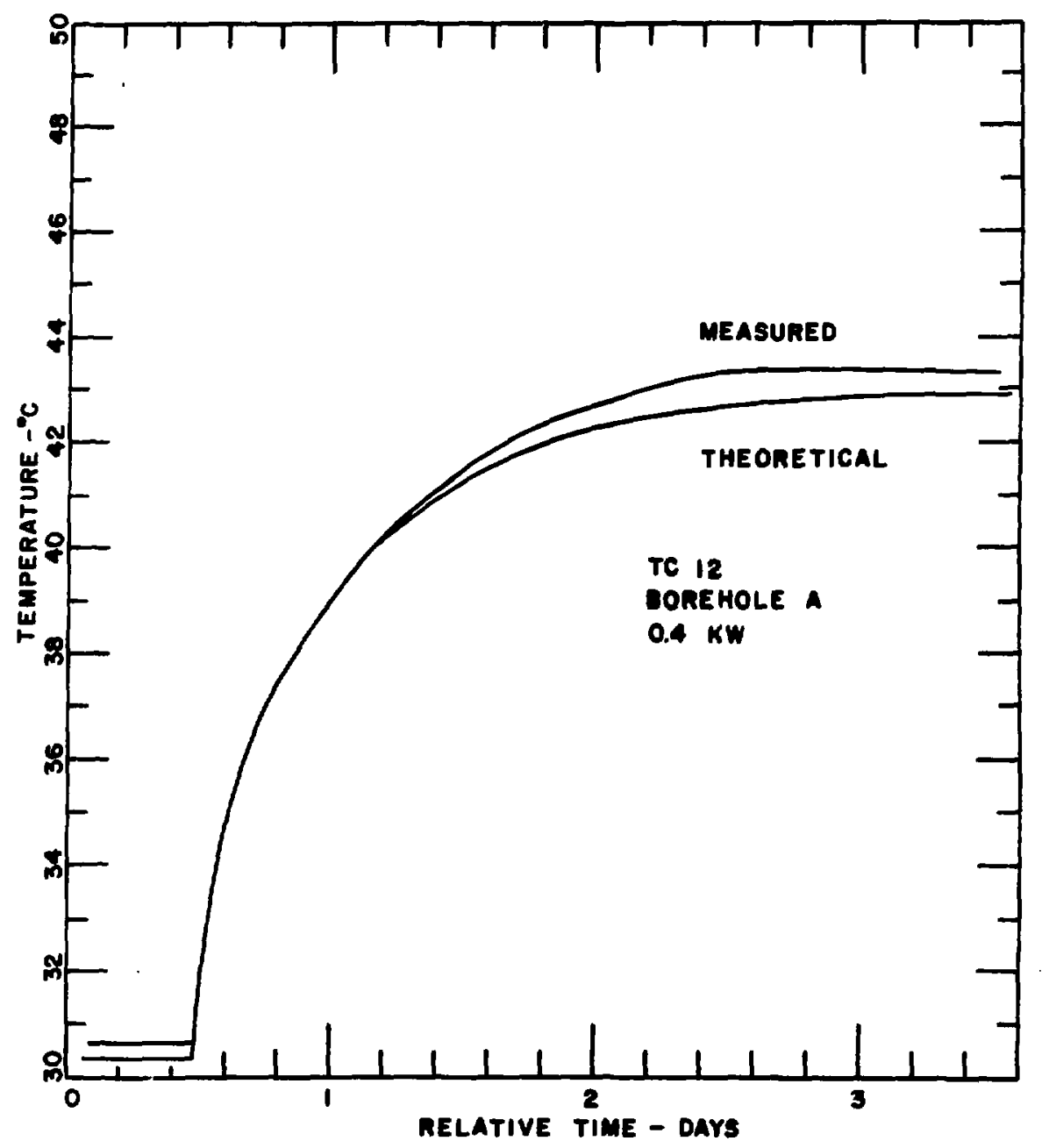

wioure 22. TETFERA TIR! OF THERMOCOUPLE 12 FOR THE HEATER DT,WER TRANSITION FROM $0.2 \mathrm{~kW}$ TO $0.4 \mathrm{~kW}$ 


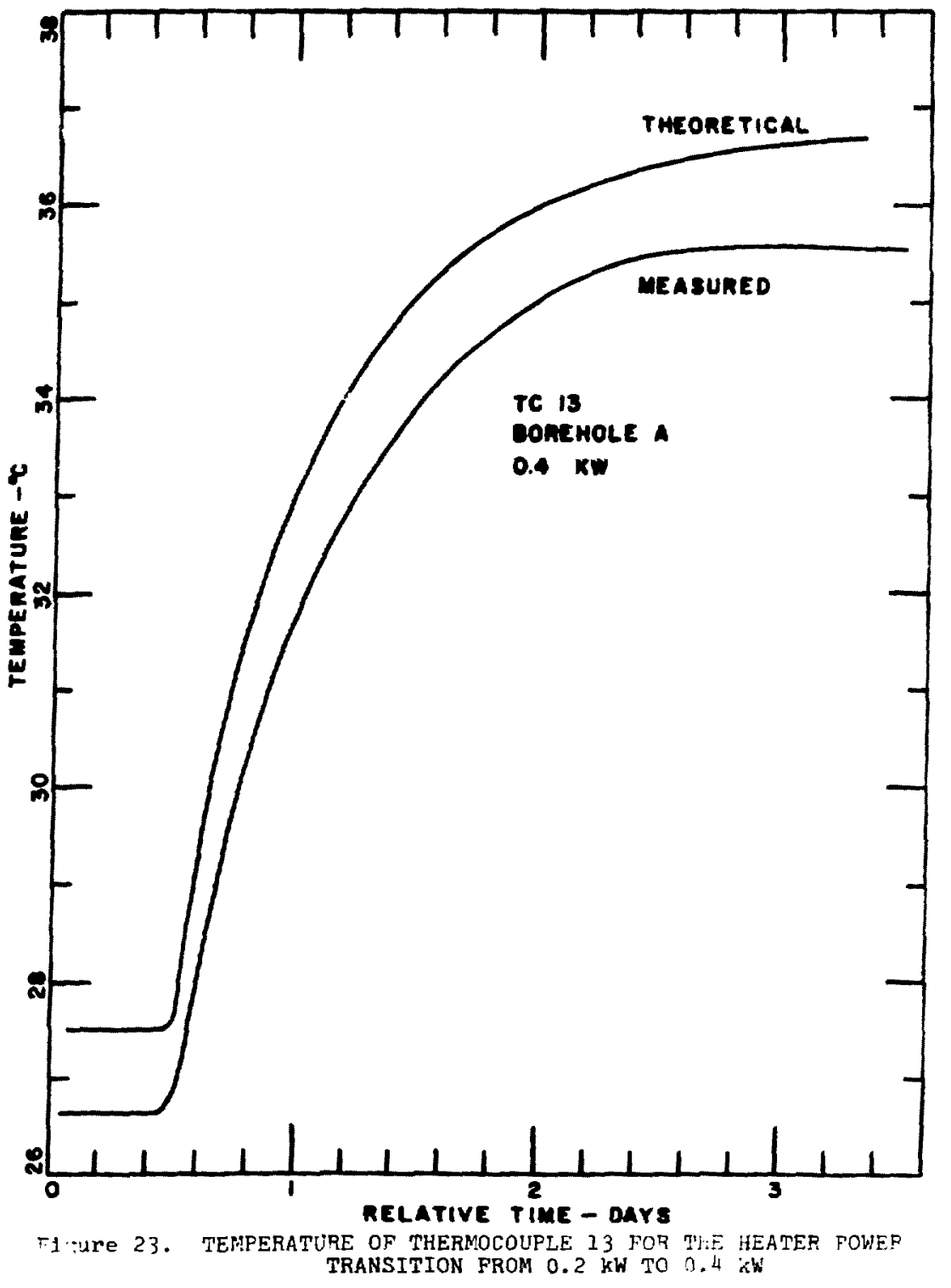




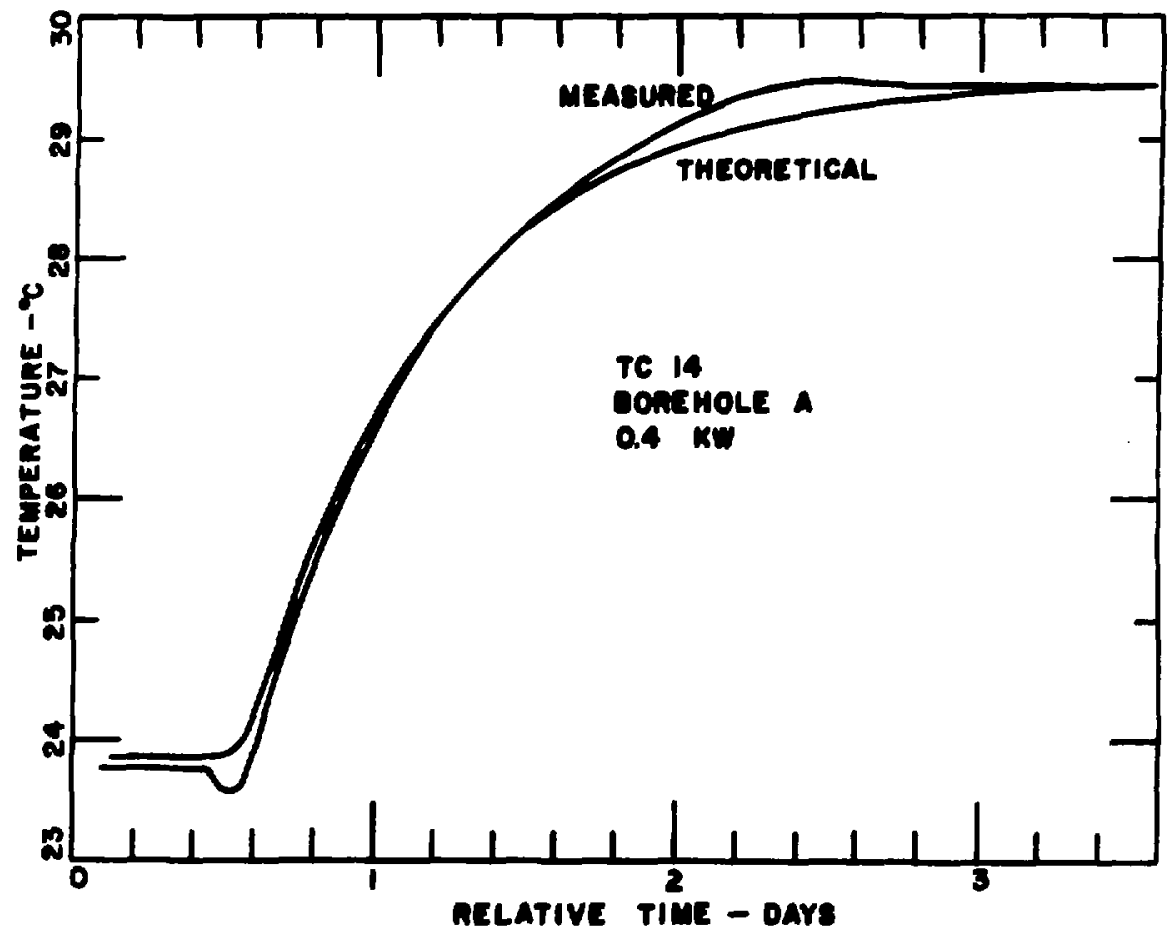

F: - UPE 24. TEMPEFATURE OF THERMOCOUPLE I4 FOR THE HEATER POWER TRANSITION FROM $0.2 \mathrm{~kW}$ TO $0.4 \mathrm{~kW}$ 
TABLE III

Salt Block II Temperatures, Tranadtion From $0.2 \mathrm{kH}$ to $0.4 \mathrm{kH}$

\begin{tabular}{|c|c|c|c|c|c|c|c|c|}
\hline \multirow[b]{2}{*}{$\begin{array}{c}\text { Thermocouple } \\
\text { Nupber }\end{array}$} & \multicolumn{4}{|c|}{ Theoret les 1} & \multicolumn{4}{|c|}{ rentured } \\
\hline & $\begin{array}{c}\text { In1tial } \\
\text { Temperature } \\
\end{array}$ & $\begin{array}{c}\text { Final } \\
\text { Temperature } \\
\text { or }\end{array}$ & $\begin{array}{c}\text { Tenperature } \\
\mathrm{Ch}_{\mathrm{o}} \mathrm{o}_{\mathrm{c}}\end{array}$ & $\begin{array}{c}\text { e-Polding } \\
\text { Tine } \\
\text { Dere }\end{array}$ & $\begin{array}{c}\text { In1tial } \\
\text { Tespotrature } \\
\end{array}$ & $\begin{array}{c}\text { Pinel } \\
\text { Tenperature } \\
\text { oc }\end{array}$ & $\begin{array}{c}\text { Teperature } \\
\text { Chynse }\end{array}$ & $\begin{array}{c}\text { e-pola1ns } \\
\text { Thes } \\
\text { Dere }\end{array}$ \\
\hline $\begin{array}{r}5 \\
6 \\
7 \\
6 \\
9 \\
10 \\
11 \\
12 \\
13 \\
14 \\
15 \\
16 \\
17 \\
18 \\
19 \\
20 \\
21 \\
22\end{array}$ & $\begin{array}{l}52.42 \pm .004 \\
50.33 \pm .004 \\
45.40 \pm .004 \\
32.69 \pm .004 \\
27.05 \pm .003 \\
25.17 \pm .003 \\
36.79 \pm .004 \\
30.63 \pm .004 \\
27.51 \pm .004 \\
23.97 \pm .002 \\
27.44 \pm .003 \\
25.76 \pm .003 \\
24.53 \pm .003 \\
22.46 \pm .002 \\
24.12 \pm .003 \\
23.62 \pm .003 \\
23.16 \pm .003 \\
22.37 \pm .002\end{array}$ & $\begin{array}{l}82.90 \pm .09 \\
79.49 \pm .09 \\
73.65 \pm .09 \\
52.74 \pm .09 \\
34.56 \pm .07 \\
31.13 \pm .06 \\
55.55 \pm .08 \\
43.01 \pm .07 \\
36.742 .07 \\
29.47 \pm .05 \\
38.83 \pm .07 \\
34.53 \pm .07 \\
31.63 \pm .06 \\
27.122 .05 \\
31.172 .06 \\
30.45 \pm .06 \\
26.89 \pm .06 \\
27.09 \pm .05\end{array}$ & $\begin{array}{r}29.49 \pm .09 \\
29.16 \pm .09 \\
28.25 \pm .09 \\
20.05 \pm .06 \\
7.51 \pm .07 \\
5.96 \pm .06 \\
16.76 \pm .08 \\
12.39 \pm .07 \\
9.23 \pm .07 \\
5.60 \pm .05 \\
11.39 \pm .07 \\
6.77 \pm .07 \\
7.10 \pm .06 \\
4.66 \pm .05 \\
7.05 \pm .06 \\
6.63 \pm .06 \\
5.72 \pm .06 \\
4.724 .05\end{array}$ & $\begin{array}{l}0.32 \\
0.33 \\
0.33 \\
0.40 \\
0.66 \\
0.69 \\
0.43 \\
0.53 \\
0.60 \\
0.66 \\
0.55 \\
0.62 \\
0.66 \\
0.71 \\
0.66 \\
0.67 \\
0.70 \\
0.73\end{array}$ & $\begin{array}{r}52.87 \pm .07 \\
99.00 \pm .09 \\
44.85 \pm .07 \\
35.33 \pm .07 \\
27.66 \pm .04 \\
25.62 \pm .03 \\
35.17 \pm .23 \\
30.36 \pm .06 \\
26.67 \pm .05 \\
23.76 \pm .05 \\
20.08 \pm .07 \\
26.22 \pm .06 \\
24.39 \pm .06 \\
22.38 \pm .04 \\
23.83 \pm .03 \\
23.51 \pm .09 \\
-23.03 \pm .62 \\
21.84 \pm .07\end{array}$ & $\begin{array}{c}83.78 \pm .14 \\
80.80 \pm .15 \\
73.19 \pm .15 \\
54.52 \pm .15 \\
35.98 \pm .00 \\
32.00 \pm .07 \\
53.14 \pm .12 \\
3 . .22 \pm .12 \\
35.52 \pm .11 \\
29.42 \pm .14 \\
39.30 \pm .09 \\
35.11 \pm .04 \\
31.17 \pm .09 \\
27.11 \pm .10 \\
30.00 \pm .04 \\
29.33 \pm .05 \\
27.41 \pm 1.36 \\
26.06 \pm .02\end{array}$ & $\begin{array}{r}31.91 \pm .16 \\
.31 .00 \pm .17 \\
28.34 \pm .17 \\
19.19 \pm .17 \\
6.32 \pm .07 \\
6.38 \pm .07 \\
17.97 \pm .25 \\
12.86 \pm .14 \\
6.85 \pm .12 \\
5.66 \pm .15 \\
11.22 \pm .11 \\
6.89 \pm .10 \\
6.784 .11 \\
4.73 \pm .11 \\
6.17 \pm .05 \\
5.82 \pm .10 \\
4.25 \\
4.22 \pm .07\end{array}$ & $\begin{array}{l}0.27 \\
0.30 \\
0.32 \\
0.41 \\
0.52 \\
0.55 \\
0.75 \\
0.52 \\
0.59 \\
0.62 \\
0.56 \\
0.62 \\
0.67 \\
0.70 \\
0.74 \\
0.77 \\
0.76\end{array}$ \\
\hline
\end{tabular}

Defective sensor cold junction. 


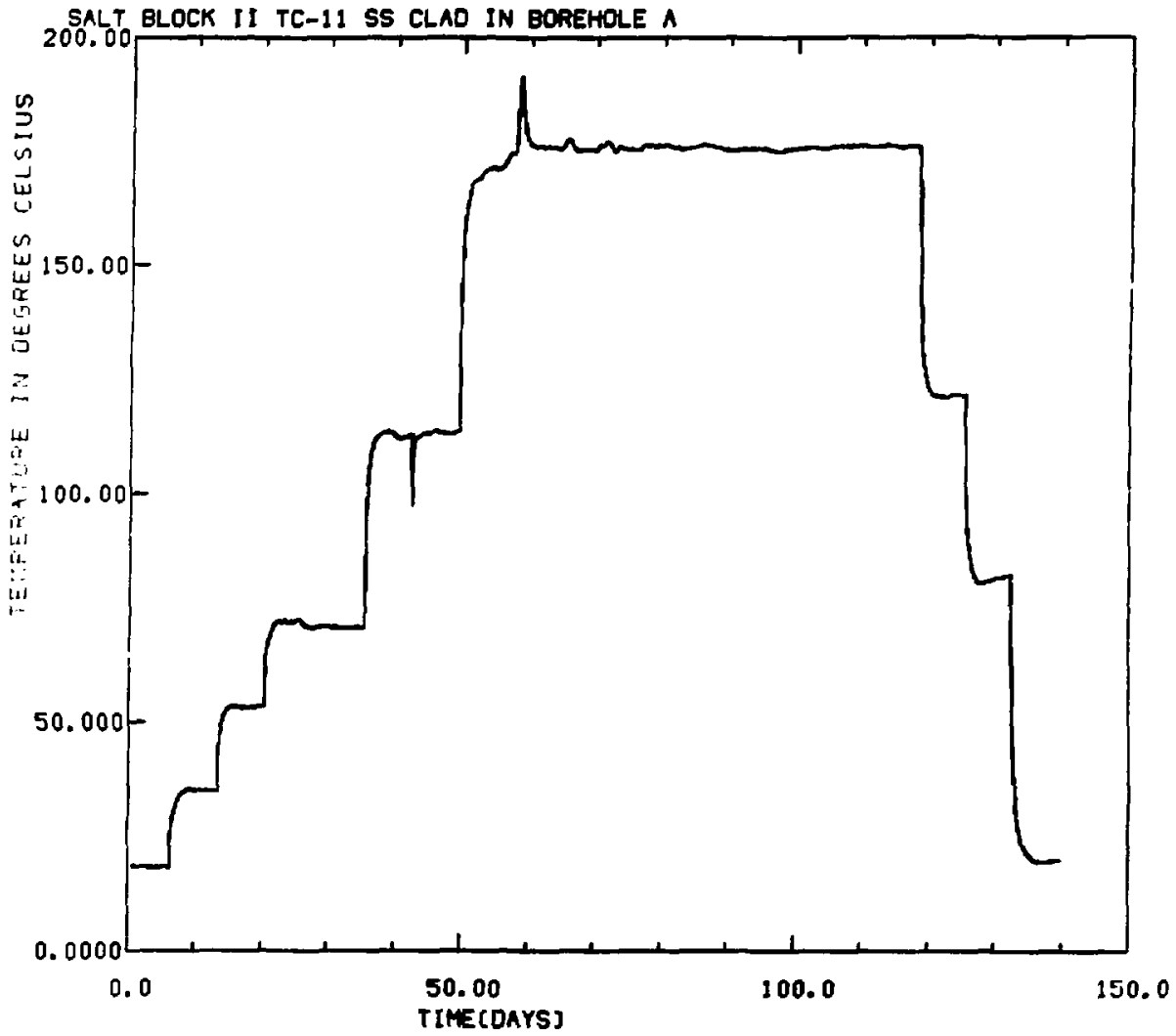

FIgure 25. TEMPERATURE MEASURED BY THERMOCOUPLE II IN MIDPLANE OF SALT BLOCK 


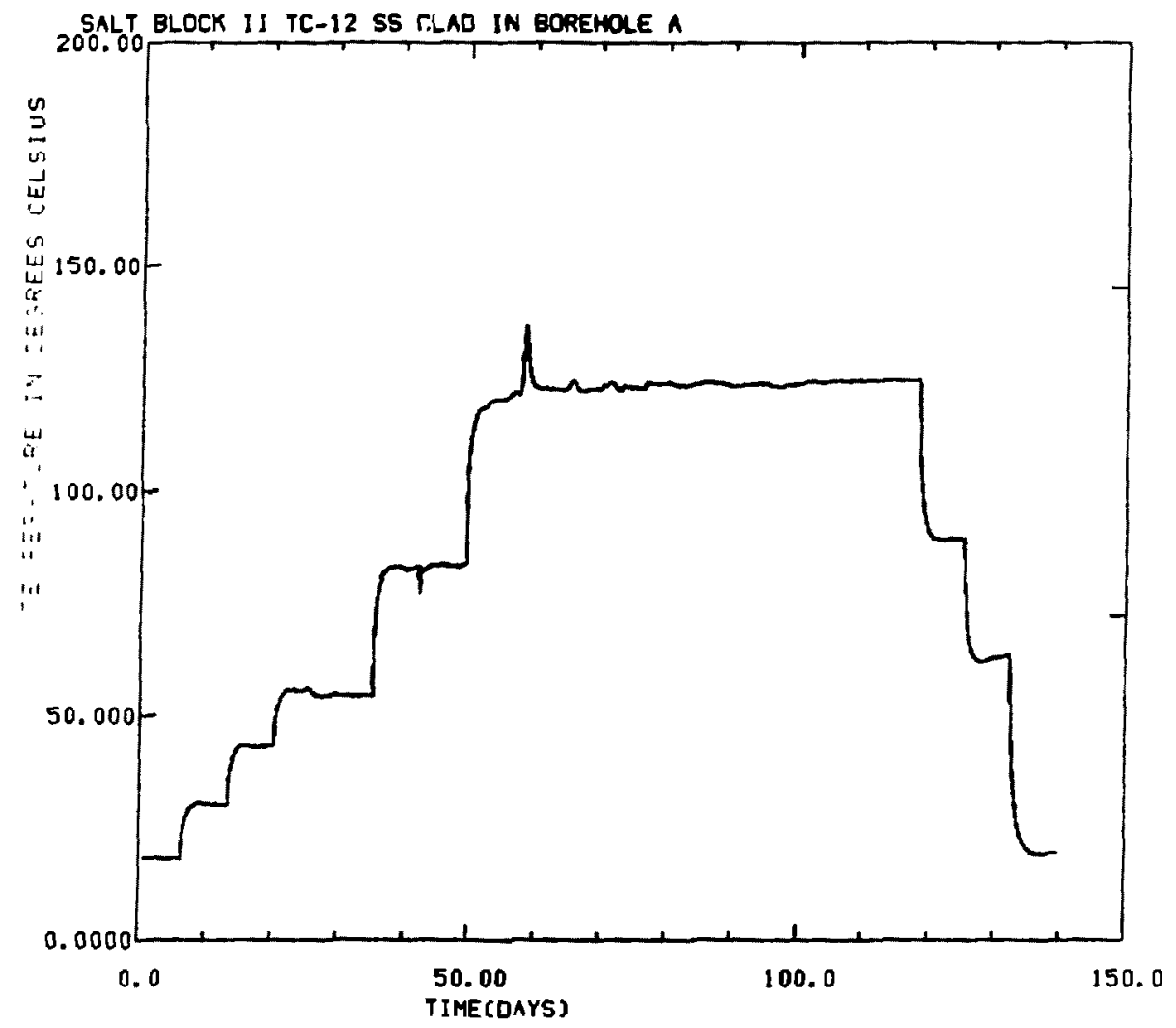

F1gure 26. TEMPERATURE MEASURED BY THERMOCOUPLE 12 IN MIDPLANE OF SALT BLOCK 


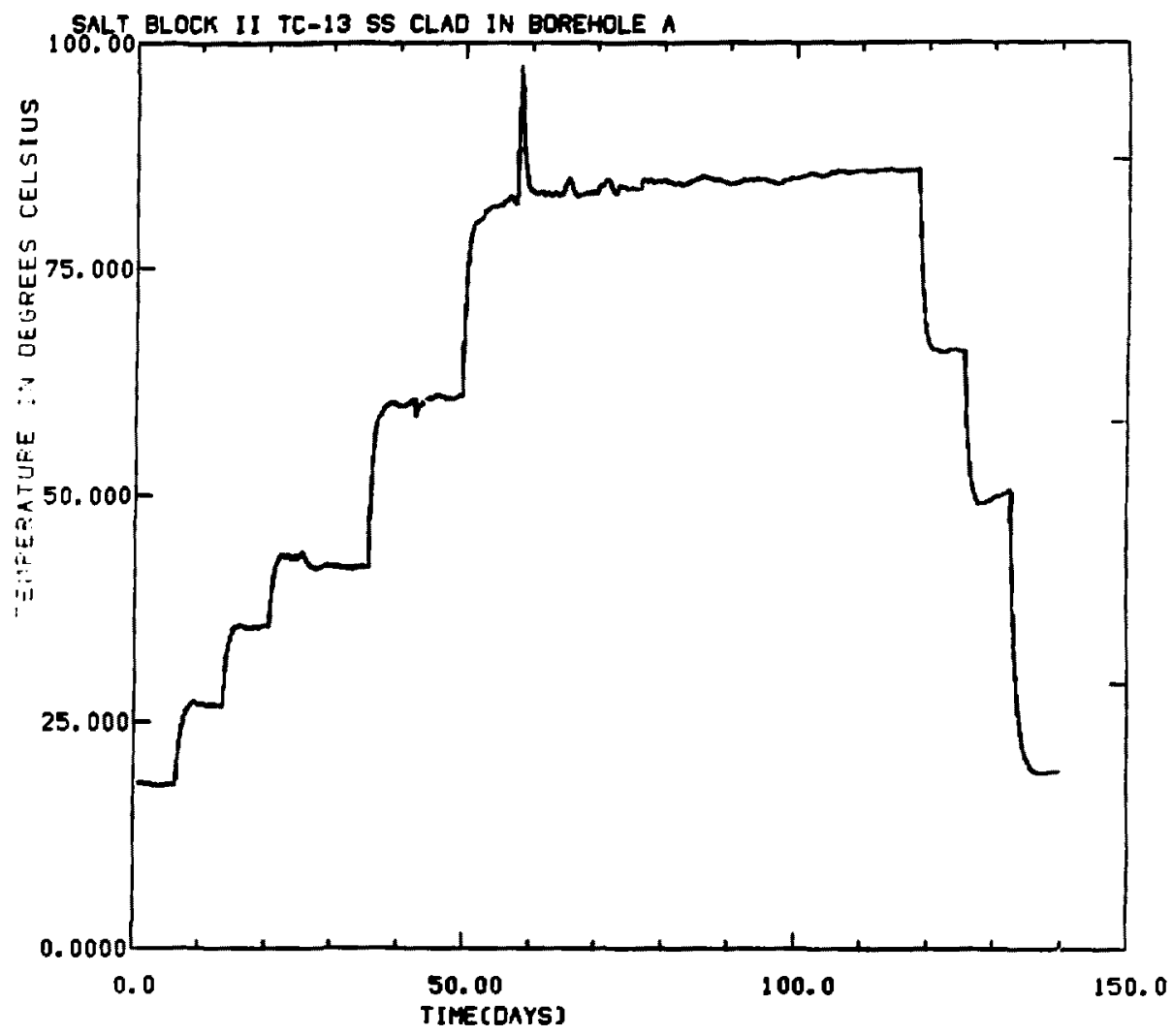

F1fure 27. TEMPERATURE MEASURED BY THERHOCOUPLE 13 IN MIDPLANE OF SALT BLOCK 


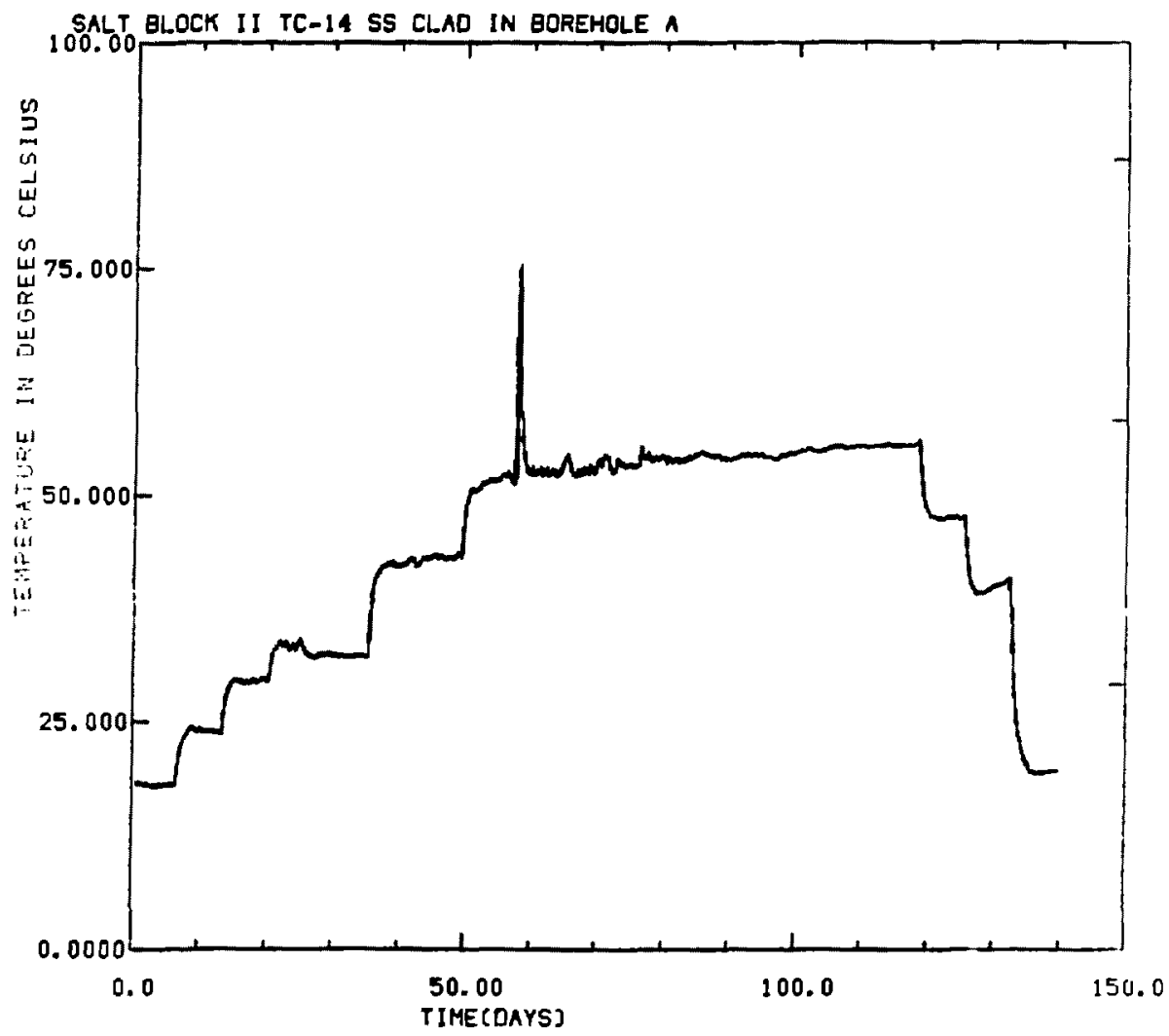

1.2.inTe 23. TLMPIERATLIRI: MEASURED BY THERMOCOUPLi 14 IN MIDPLANE OF SALT BLOCK 


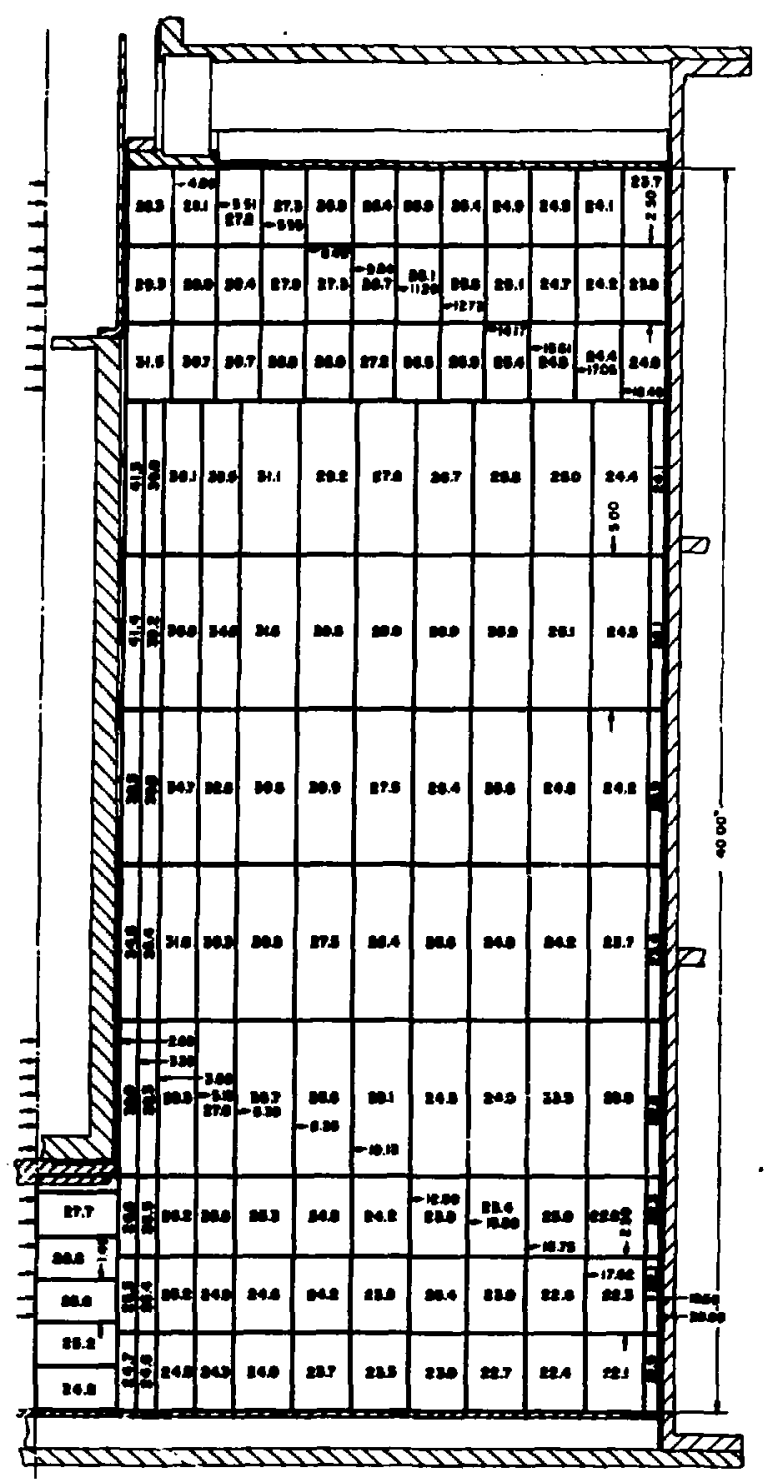

F1gure 29. CALCULATED EQUILIBRIUM TEMPERATURES $\left({ }^{\circ} \mathrm{C}\right)$ IN SALT BLOCK FOR $0.2 \mathrm{~kW}$ HEATER POWER 



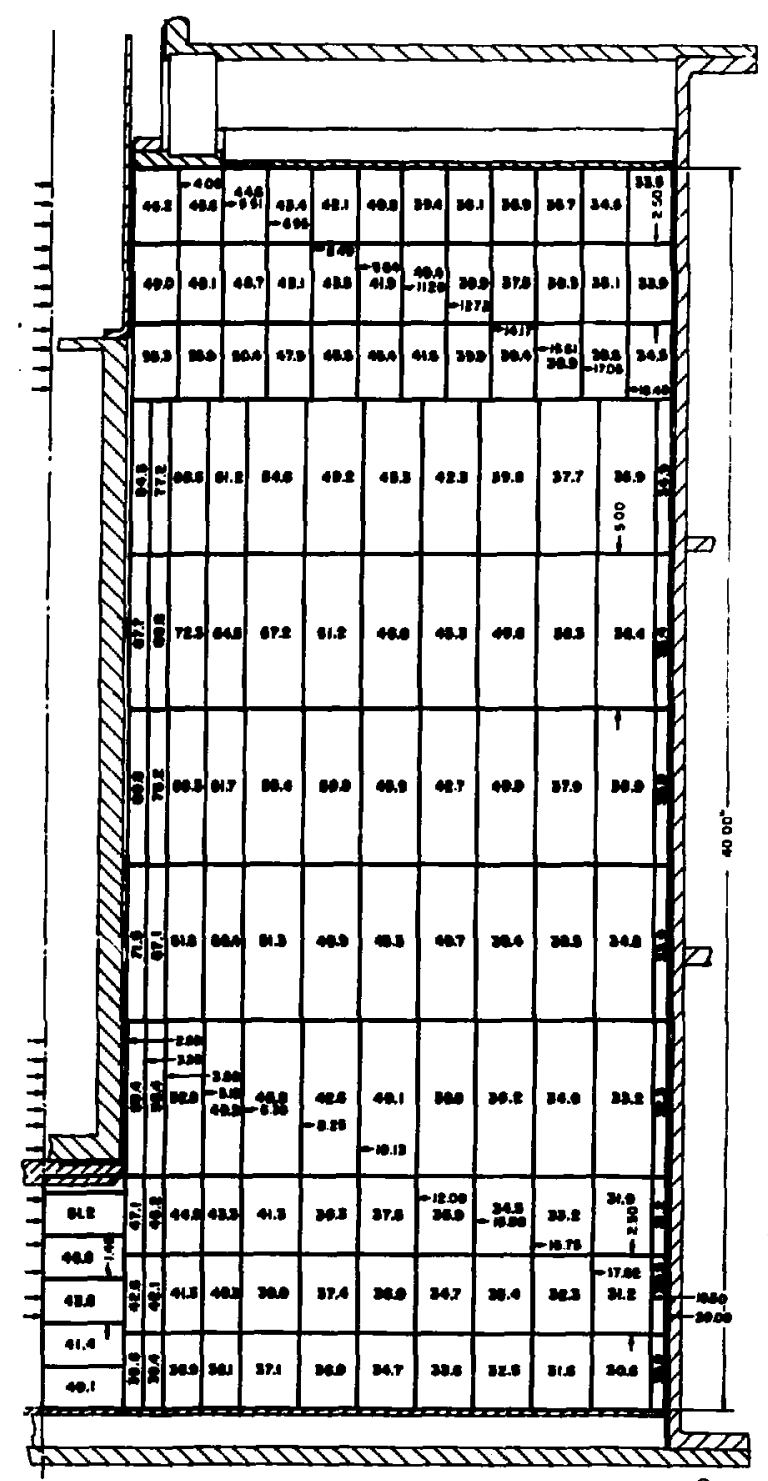

Figure 31. CALCULATED EQUILIBRIUM TEMPERATURES $\left({ }^{\circ} \mathrm{C}\right)$ IN SALT BLOCK FOR $0.6 \mathrm{kN}$ HEATER POWER 


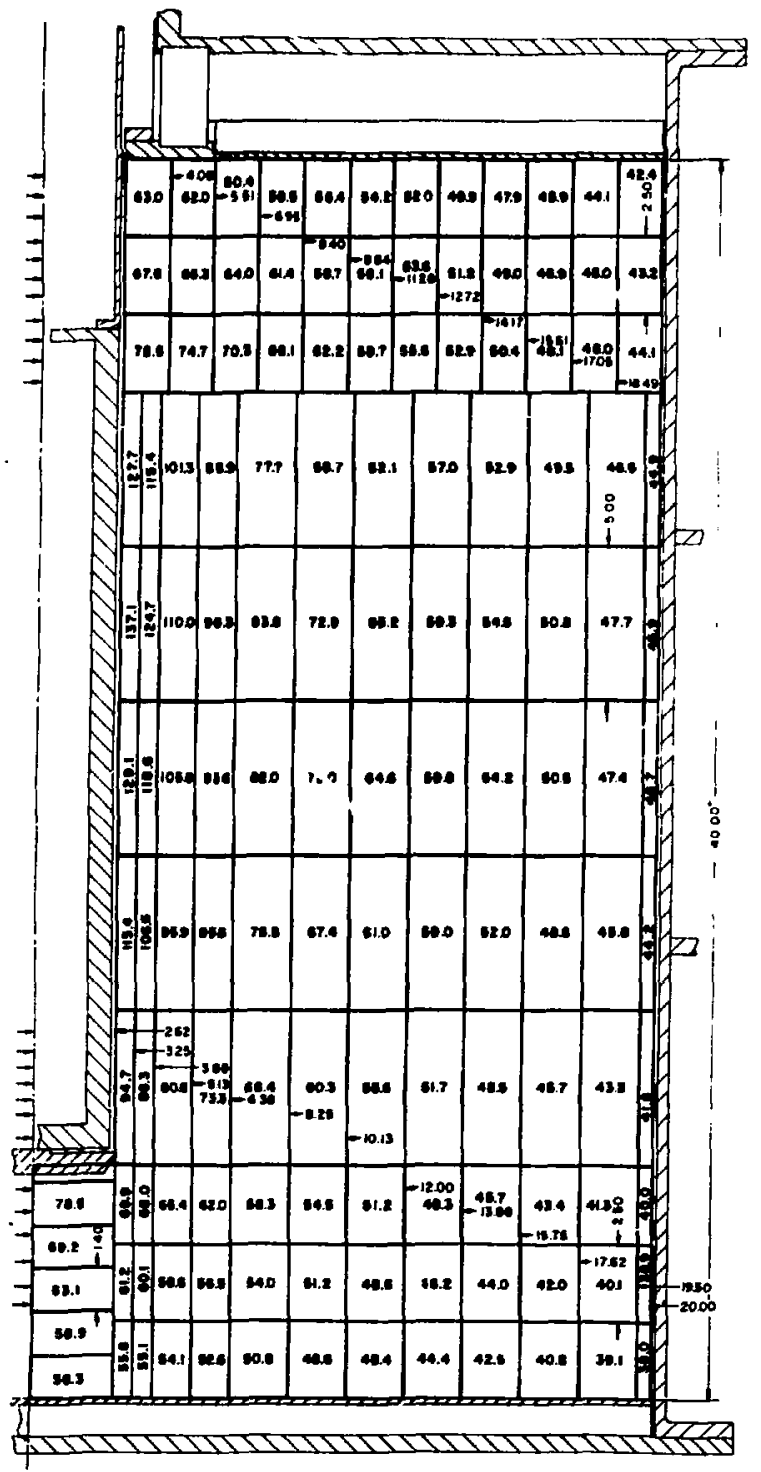

FIgure 32. CALCULATED EQUILIBRIUM TEMPERATURES $\left({ }^{\circ} \mathrm{C}\right)$ IN SALT BLOCK FOR $1.0 \mathrm{~kW}$ HEATER POWER 


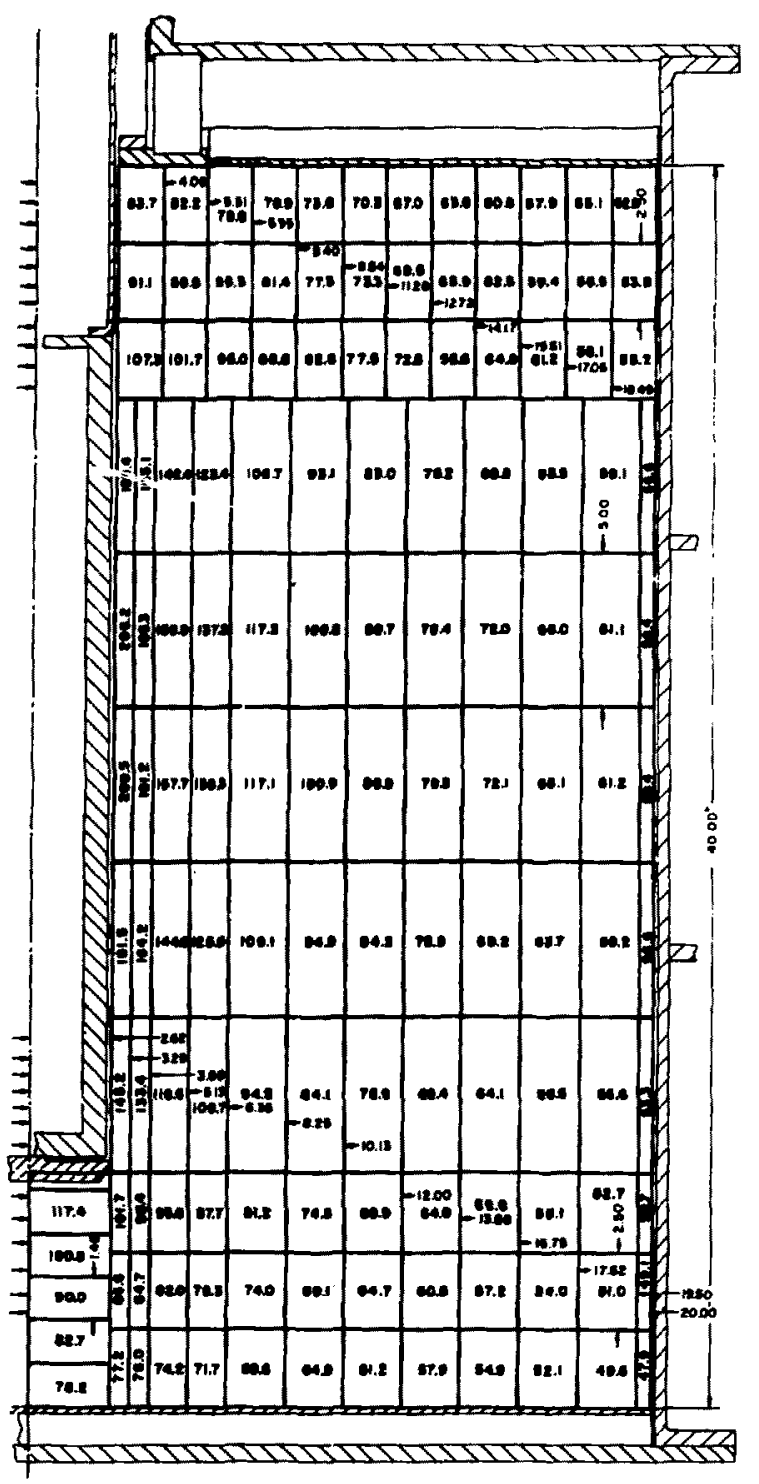

Figure 33. CALCULATED EQUILIBRIUM TEMPERATURES $\left({ }^{\circ} \mathrm{C}\right)$ IN SALT BLOCK FOR $1.5 \mathrm{~kW}$ HEATER POWER 


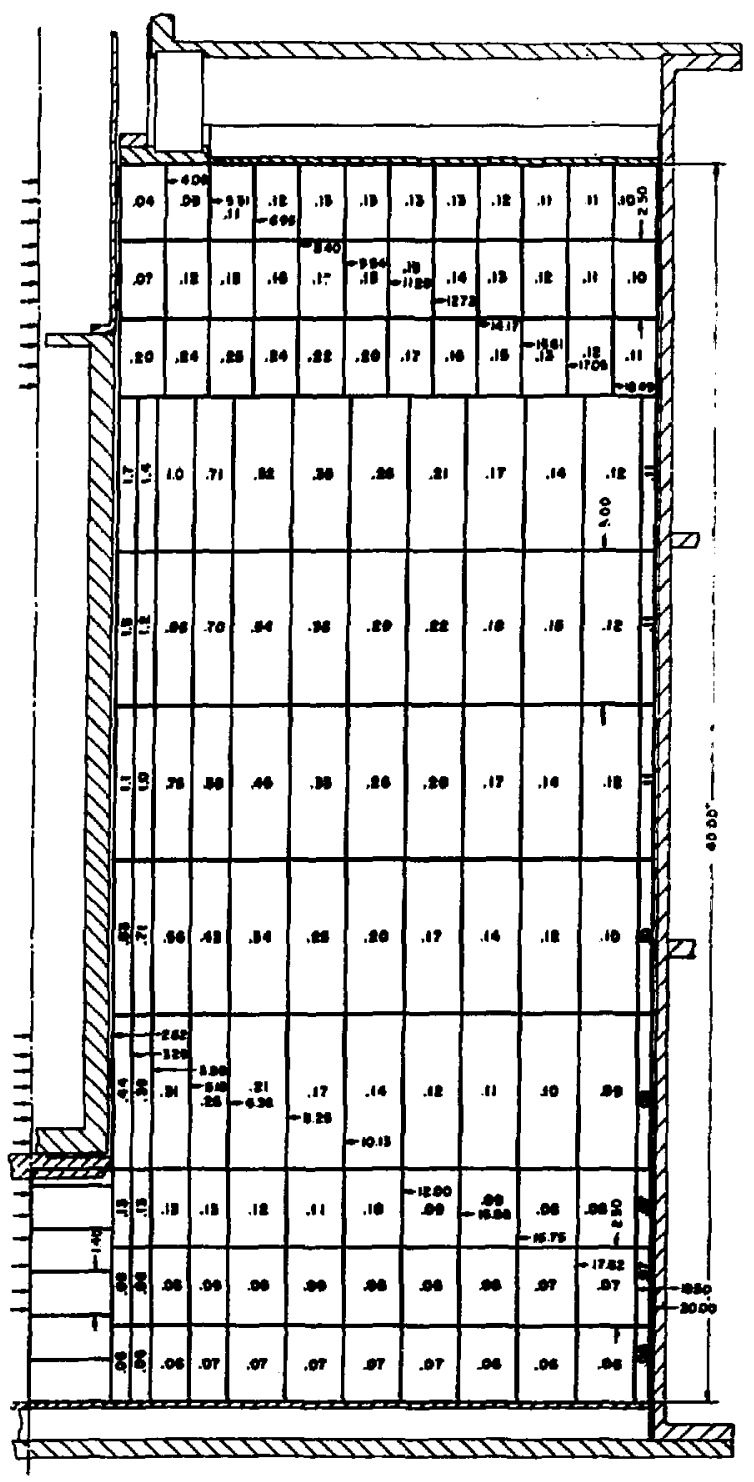

Figure 34. ABSOLUTE VALUE OF THE CALCULATED RADIAL COMPONENT OF THE EQUILIBRIUM THERMAL GRADIENT $\left({ }^{\circ} \mathrm{C} \cdot \mathrm{cm}^{-1}\right)$ IN SALT BLOCK POR $0.2 \mathrm{~kW}$ HEATER POWER 


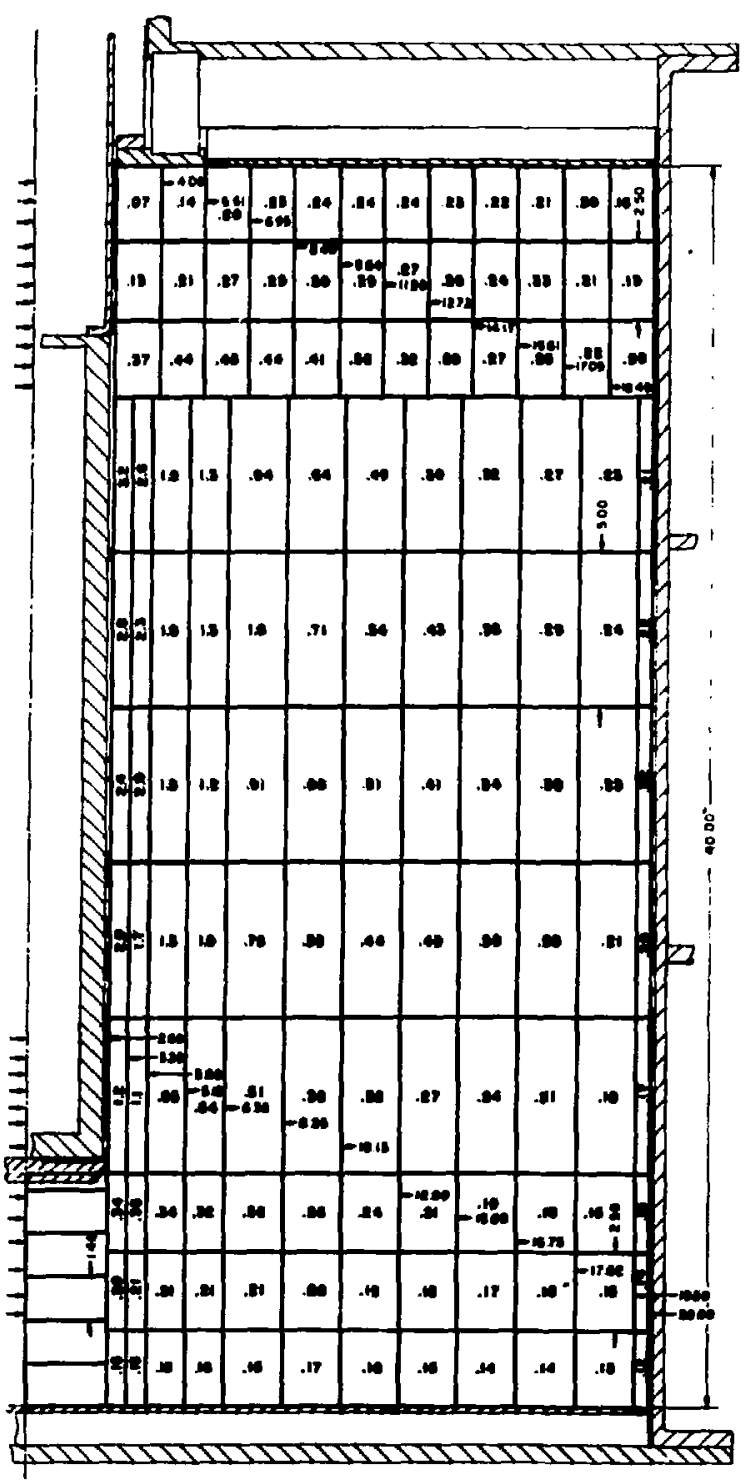

F1gure 35. ABSOLUTE VALUE OF THE CALCULATED RADIAL, COMPONENT OF THE EQUILIBRIUM THERMAL GRADIENT $\left({ }^{\circ} \mathrm{C} \cdot \mathrm{cm}^{-1}\right)$ IN SALT BLOCK FOR $0.4 \mathrm{~kW}$ HEATER POWER 


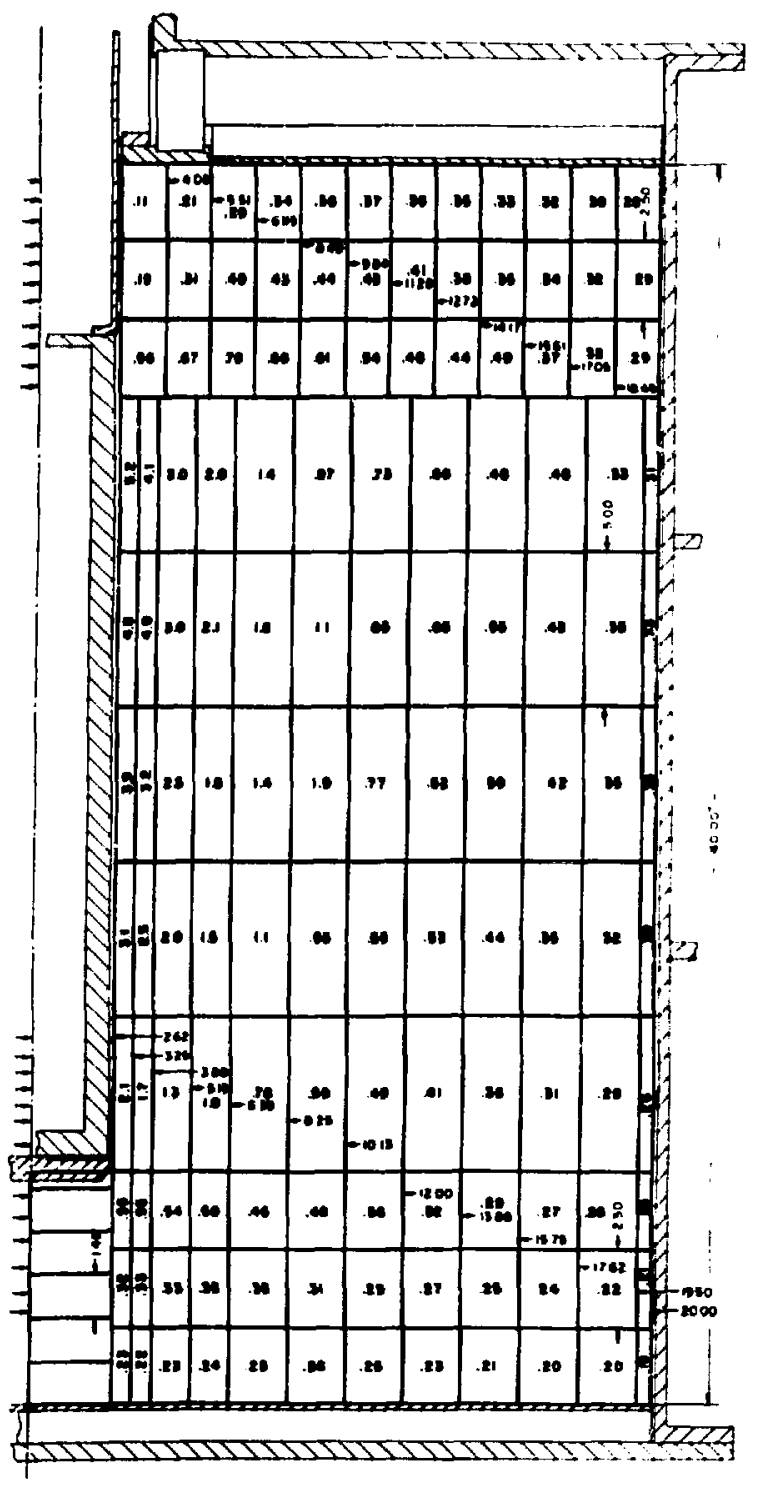

F1gure 36. ABSOLUTE VALUE OF THE CALCULATED RADIAL COMPONENT OF THE EQUILIBRIUM THERHAL GRADIEIT $\left({ }^{\circ} \mathrm{C} \cdot \mathrm{cm}^{-1}\right)$ IN SALT BLOCK FOñ $0.6 \mathrm{~kW}$ HEATER POWER 


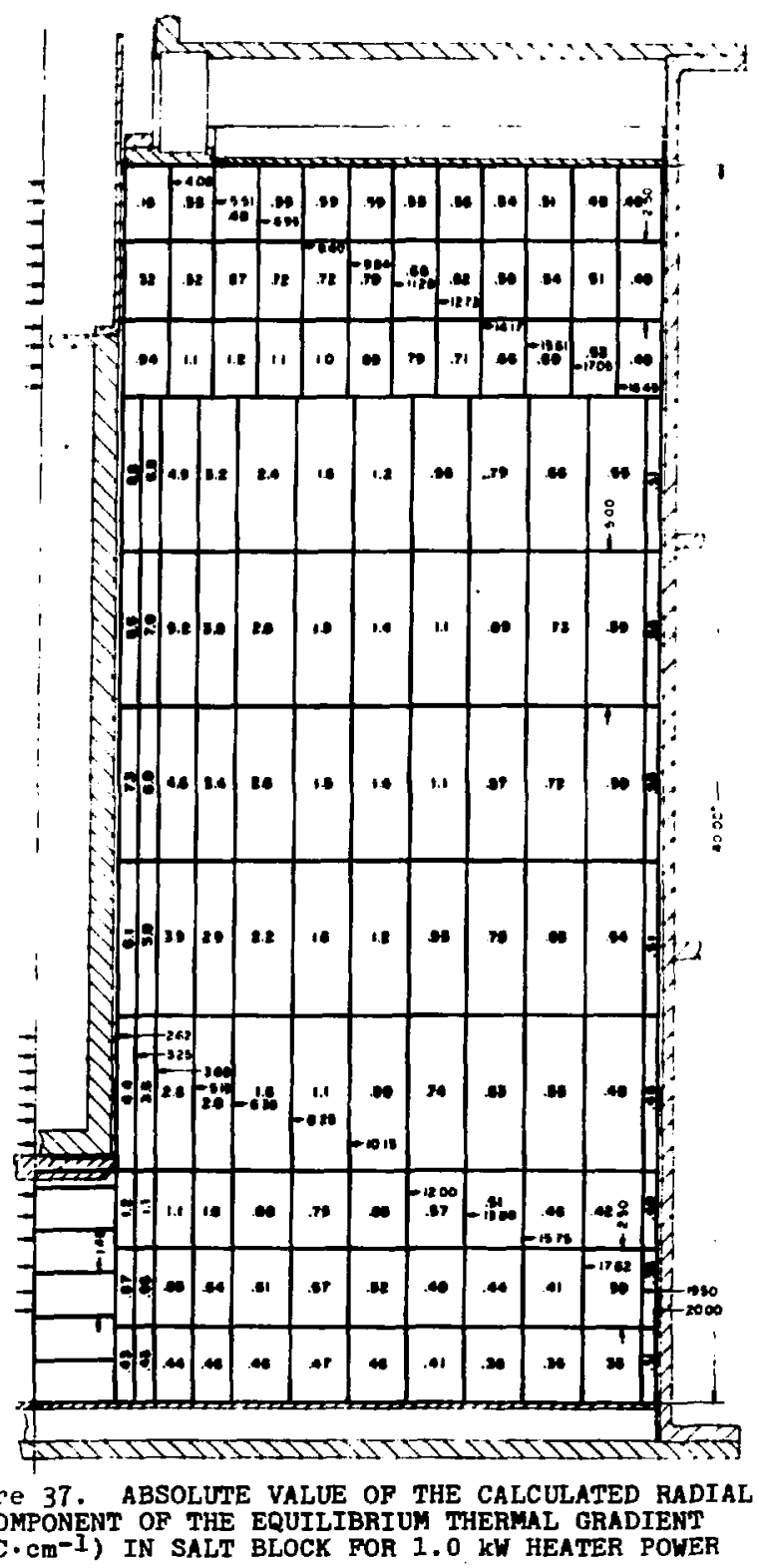




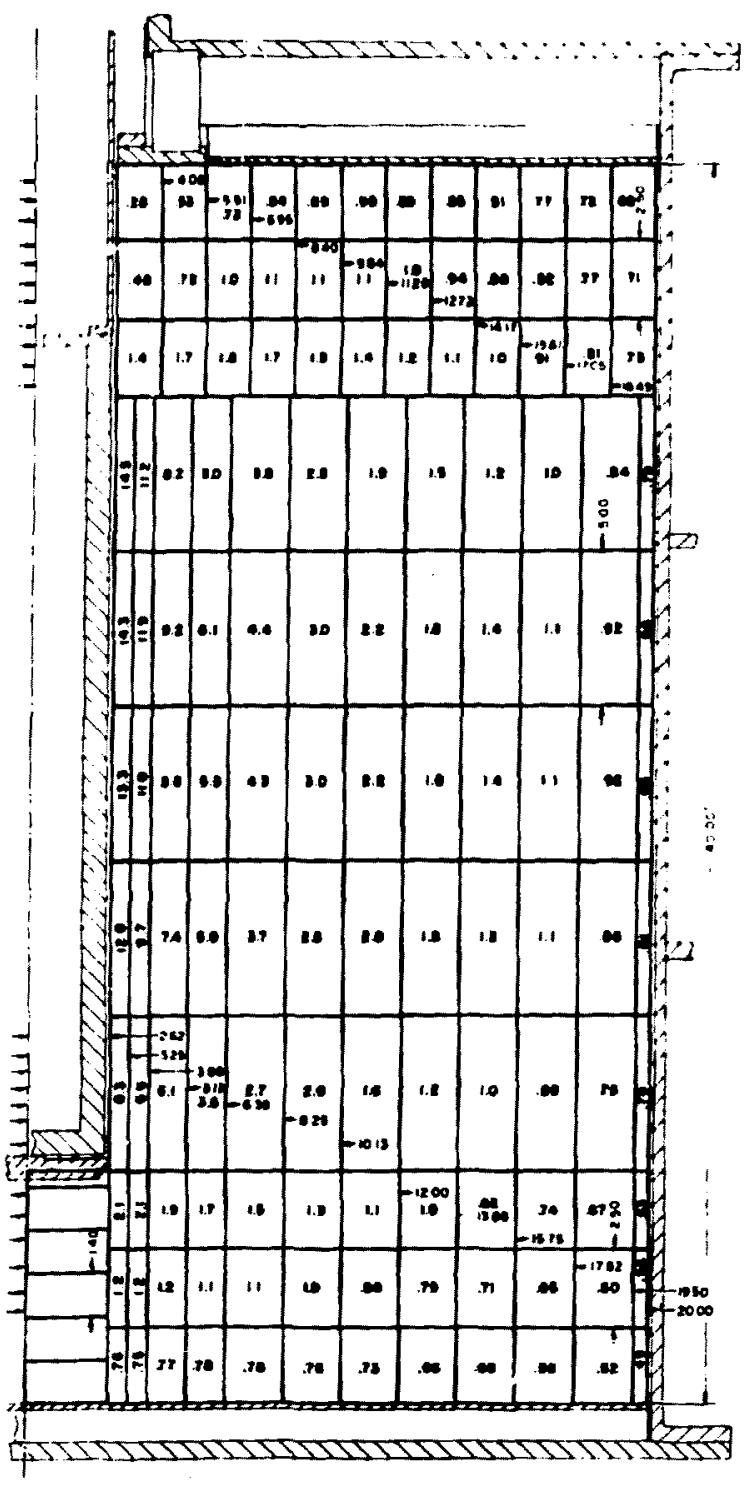

FIFure 38. ABSOLUTE VALUE OF THE CALCULATED RADIAL COPPONENT OF THE EQUILIBRIUM THERMAL GRADIENT $\left({ }^{\circ} \mathrm{C} \cdot \mathrm{cm}^{-1}\right)$ IN SALT BLOCK FOR $1.5 \mathrm{~kW}$ HEATER POWER 
disks have been copied onto 9-track nagnetic tape. These data will be transferred, in part, onto 7-track magnetic tape as peranant files.

\section{Drecussion}

The most eignificant observations of this experiment are the timedependent nature of the meter releave rates.' warge increases in the meter release rate ere observed following changes in the henter powr. The greateat wet-release rates wre oberved following decreases in the heater power. The measured water-release rates are in qualitative ggresment with similar measurenents ads on hated $1 \mathrm{~kg}$ ealt eamples. non bedley (5511) is developing a water trancport sodel that predicts meter-release rates that agree quantitatively with the masured meter-releace rates. It appers that the thermonechanical response of the anlt, including the strese state and time-dependent stress relaxation, is on esential ingredient in fordicting the measured wter celeace rates. ${ }^{3}$ The large increase in the water flow rate following a decrease in the hater power aries becwe the salt fails in tension with the resultant increase in its pormenbllity.

The total weter released during the exporinent (111.4 pl is mall compared to the block's mter content (from batwen $2.2 \mathrm{~kg}$ and $9.0 \mathrm{~kg}$ ). The data presented in Fiyure 10 provids com indication of unter depletion in the material surcounding the bocehole at dietences up to bout $0.08 \mathrm{~m}$ erom the borehole's surface. Note that the mter content of this annular volume surrounding the bochole 11 es betwen 329 and 133 g wich if of the order of that wich we releaced into the borthole. Significant water traneport probably cccurred only in a enll region ourrounding the bochole.

Microscopic exanintion of the pout-tent cored wlt from material adjacent to the bocehole revealed radially orlented tracks, which wre highly non-unitorn in length (up to $10=1 \mathrm{cmg}$ ) and epatial distribution. Bowe of these tracks containad fluid. sinilar tracks wre not oberwa in comparable but unherated geologic enIt. These tracke my be evidence of the physical transpoct of fluids along therwal grediente, but theif aignificance to the evolved mater measured in this experinent has not been established. 
The good agreetment between thermal measurements and calculated values of the thermal field within the calt block indicate that our knowledge of the salt block's time-dependent temperature distribution is adequate for any post-test andyses or modeling. In this regard, the vertical spatial distefbution of power from the cylindrical hater we not only non-uniform but varied with heater power. For low heater power levelg (Up to $0.4 \mathrm{~kW}$ ), most of the heater's power is released from its upper portion wile at high hester power (greater than $1.0 \mathrm{kH}$ ), the spatial dietribution of the hater's power shif ts toward the heater's aldplene. Mesured values of the salt's thermal conductivity in the region from $18^{\circ} \mathrm{C}$ to $200^{\circ} \mathrm{C}$ range from $5.5 \mathrm{w}^{\circ} \mathrm{c}$ $\mathrm{m}^{-1}$ to $3.6 \mathrm{w}^{\circ} \mathrm{c}^{-1}, \mathrm{~m}^{-1}$ at thece tenperatures, respetively; these are consistent with other measurements of thermal conductivity determined on smaller samples. 5

Further anslysis of the data is not expected to alter aignificantly the material presented here. "Fine-tuning" of the thernal sodel by introducing, for example, a time-dependent, thermal resistance at the calt-atainless steel shell interface is poseible elthough unnecensary for anticipated watertransport calculations. Pont-test chenical analyois of the crushad anlt backfill around the heater and chenical and ainerological analysis of the salt block are continuing. Amalyes of the beckelll material are consintent with the mensured weter released into the borehole region. Refirement of existing weter-transport modelo to include the thermonechanical properties of the salt, together with the selt block's time-dspendent temperature eleld, in order to predict unter transport retes is where subsequent ef lorts should be expended. 
1. Hohlfelder, J. J., Masurement of Water Lost From Heated Geologic Salt, SAND79-0462, Sandia Hational Laborator 1es, Albuquerque, Mew Mexico, 1979.

2. George, 0., Computer Thermal rodeling for the salt Block II Bxperiment, SAND79-2250, Sandia Mational Laboratorles, Albuquerque, New Maxico (to be publiahed).

3. Hohlfelder, J. J. and G. R. Hedley, Laboratory szudies of Water Trancport in Rock Balt, BND79-1519, sandia maticnal Luboratories, Albuquerque, New Haxico, 1979.

4. Lambert, S. J., Minaralogical Aepecte of Fluld Migration in the salt Block II Exper Lnent, sMid79-2423, sandie Uational Laboratories, Albuquerque, New Haxico, May 1980.

5. Acton, R. V.. Thermal Conductivity of 82 wew Mexico Rocksalt and Anhydrite, unpublished sandia Mational Laboratories prelininary report, 1977. 